\title{
Conodont biostratigraphy of the Nalai section (Guangxi) and new data on the age of the Zdimir beds in South China
}

\author{
JIANFEng LU, JOSÉ IGNACIO VALENZUELA-RíOS, XIUQIN CHEN \& JAU-ChYN LIAO
}

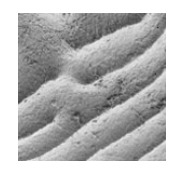

\begin{abstract}
The conodont biostratigraphy of the lower part of the Beiliu Formation at the Nalai, Guangxi is described. The association of Polygnathus serotinus, P. cooperi cooperi, P. cracens, P. linguiformis bultyncki and Bipennatus cf. $B$. montensis indicates that this stratigraphic interval, in which one Zdimir bed crops out, can be assigned to the serotinus Zone. Bipennatus cf. B. montensis, which closely resembles B. montensis from the Eifelian costatus Zone, is recorded from a relatively lower level in the Emsian serotinus Zone. The stratigraphic distribution of Zdimir in South China is further reviewed at seven sections where abundant specimens of Zdimir have been reported. Several Zdimir beds which were previously correlated with the patulus Zone are assigned to the serotinus Zone herein. The zonal correlation of these seven sections suggests that the Zdimir beds in South China belong to the serotinus Zone and to the partitus Zone. - Key words: Zdimir, Beiliu Formation, serotinus Zone, Emsian, conodont.
\end{abstract}

LU, J., VAlenZuela-Ríos, J.I., CHEN, X. \& LiAO, J.C. 2017. Conodont biostratigraphy of the Nalai section (Guangxi) and new data on the age of the Zdimir beds in South China. Bulletin of Geosciences 92(4), 525-544 (9 figures, 1 table). Czech Geological Survey, Prague. ISSN 1214-1119. Manuscript received October 28, 2016; accepted in revised form January 31, 2017; published online December 31, 2017; issued December 31, 2017.

Jianfeng Lu \& Xiuqin Chen, Nanjing Institute of Geology and Palaeontology, Chinese Academy of Sciences, East Beijing Road 39, 210008 Nanjing, PR China; jflu@nigpas.ac.cn, xqchen@nigpas.ac.cn・José Ignacio Valenzuela-Ríos \& Jau-Chyn Liao, Department of Botany and Geology, University of Valencia, c/Dr. Moliner 50, E-46100 Burjassot, Spain; jose.i.valenzuela@uv.es, jau.liao@uv.es

The genus Zdimir is represented by a group of large, thick-shelled and strong costate brachiopods that has been widely reported in the upper Emsian and the lower Eifelian in Spain, France, Belgium, Germany, Austria, Czech Republic, Poland, Urals, Kuznetsk Basin, South Tian-Shan, Mongolia, Japan and Australia (Andronov 1961, Boucot \& Siehl 1962, Ivanova 1962, Krilova 1962, Malygina \& Sapelnikov 1973, Rzhonsnitskaia 1975, Tazawa 1988, Talent \& Mawson 1994, Chen \& Tazawa 2003, Chen \& Liao 2006, Yolkin et al. 2008, Suttner \& Chen 2009, Suttner personal communication). In South China, Zdimir has also been recorded from the Dafengmen section at Beiliu (Wang et al. 1965, Hou \& Xian 1975, Wang \& Zhu 1979, Yu \& Kuang 1982), Liujing section at Hengxian (Kuang et al. 1989), Qinjia section at Debao (Wu \& Yan 1980, Xian et al. 1980), Bahe section at Tiandeng (Bai \& Bai 1988, Bai et al. 1994, Bai et al. 1998), Guanziyao section at Pu'an (Hou \& Xu 1964, Hou \& Xian 1975, Wang \& Zhu 1979, Xiong 1987) (Fig. 1), and Guixi-Shawozi section at Longmenshan (Yoh 1956, Hou et al. 1988).
Bai \& Bai (1988), and Bai et al. (1998) demonstrated that the stratigraphic distribution of Zdimir in South China ranges from the upper Emsian (the serotinus Zone) to the lower Eifelian (the costatus Zone). Moreover, Bai et al. (1998) also noted that the Zdimir beds in Guangxi, Yunan, Guizhou and Sichuan could be further assigned to the serotinus, patulus and partitus zones. However, the assignation of some Zdimir beds by Bai et al. (1998) to the patulus Zone and partitus Zone at the Bahe, Dafengmen, and Qinjia sections has to be revised, because several important conodont and rugose coral studies (Yu et al. 1979; Xiong 1981, 1987) related to these sections were not taken into consideration. The rugose coral researches also play an important role in the stratigraphic correlation herein when detailed conodont researches at some studied sections are pending. The main goals of this paper are to study the age of the Zdimir bed at the Nalai section by means of conodonts and to review the age assignations of the Zdimir beds in relevant sections from South China. 


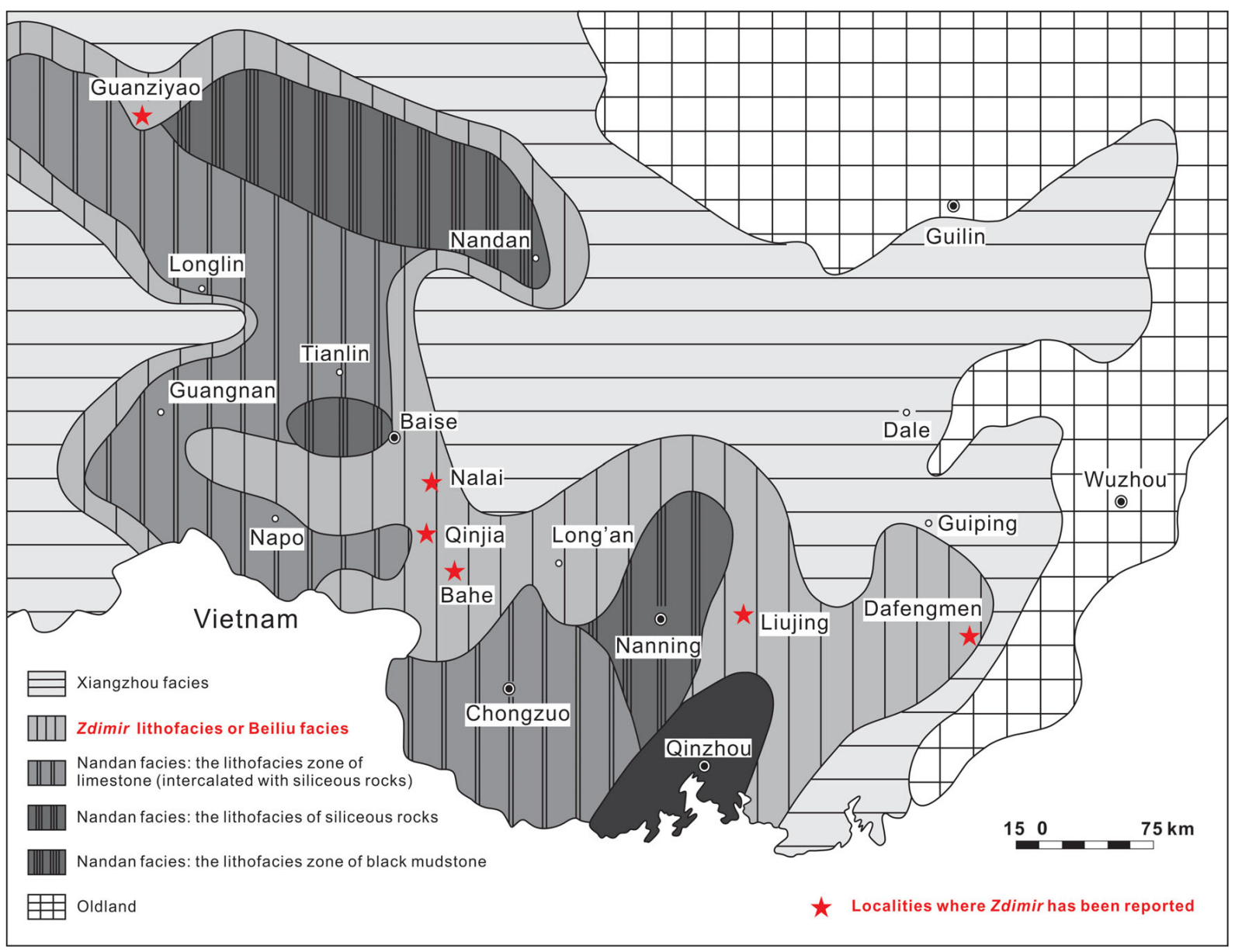

Figure 1. The geographical distribution of Zdimir in South China during the late Emsian to early Eifelian (modified after Xian et al. 1980). The red stars represent the localities where the Zdimir beds have been reported.

\section{Geological setting}

A continuous succession of strata from the Lower Devonian Huangjingshan Formation to the Lower-Middle Devonian Beiliu Formation is well exposed along the country road (Fig. 2A) at the Nalai section (Figs 1, 3; $23^{\circ} 34^{\prime} 56^{\prime \prime} \mathrm{N}$, $\left.106^{\circ} 46^{\prime} 32^{\prime \prime} \mathrm{E}\right)$. This section is situated about $1.5 \mathrm{~km}$ northeast of the Nalai Village, Pohong Town, Baise. Wang et al. (1965) named the Beiliu Formation and subdivided it into the Huangjingshan, Guitang, and Yarang members in ascending order. Later, Wang et al. (1974) formally raised the rank of the Huangjingshan Member to a formation, leaving the Guitang and Yarang as members of the Beiliu Formation. Subsequently, Zhong et al. (1992) further raised the Beiliu Formation to a group consisting of the Guitang and Yarang formations. However, due to the great difficulty in differentiating the Guitang and Yarang formations because of similar development in the Pohong area, the stratigraphic subdivision of Wang et al. (1974) is followed herein. The lower part of the Beiliu Fm. at the Nalai section conformably overlies the Huangjingshan Fm. (thick- bedded dolomite in the upper part). The Beliu Fm. is about $72.5 \mathrm{~m}$ thick and is composed of black and dark grey, thin to thick-bedded limestone. Twenty-one conodont samples were collected at this section (Fig. 4).

\section{Methods}

The limestone samples, weighing between $1.645 \mathrm{~kg}$ and $6.020 \mathrm{~kg}$, were reduced mechanically to a size of approximately $5 \mathrm{~cm}$ in diameter and then dissolved in dilute acetic acid (5-10\%). The insoluble residues were washed, air-dried and concentrated by sodium polytungstate heavy-liquid separation. Concentrated residues were hand-picked under a stereo microscope. Selected gold-coated specimens were photographed using a Scanning Electron Microscope (SEM) in the Nanjing Institute of Geology and Palaeontology, Chinese Academy of Sciences. Only thirteen limestone samples yielded conodont elements and five species or subspecies were identified from fifty-two relatively intact Pa elements (Table 1). 

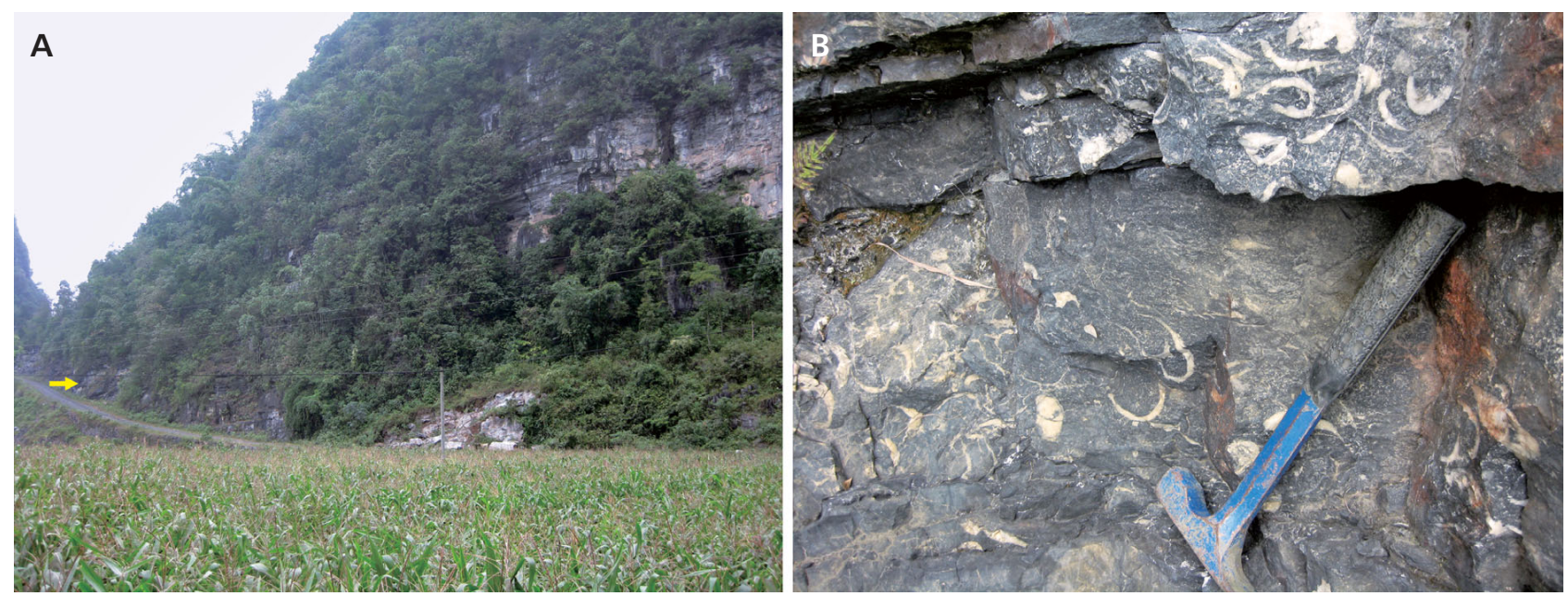

Figure 2. Outcrop view of the Nalai section with an arrow indicating the level of the Zdimir bed (A). The Zdimir bed in the upper part of bed 10 of the Beiliu Formation (B); the length of geological hammer is about $31.5 \mathrm{~cm}$.

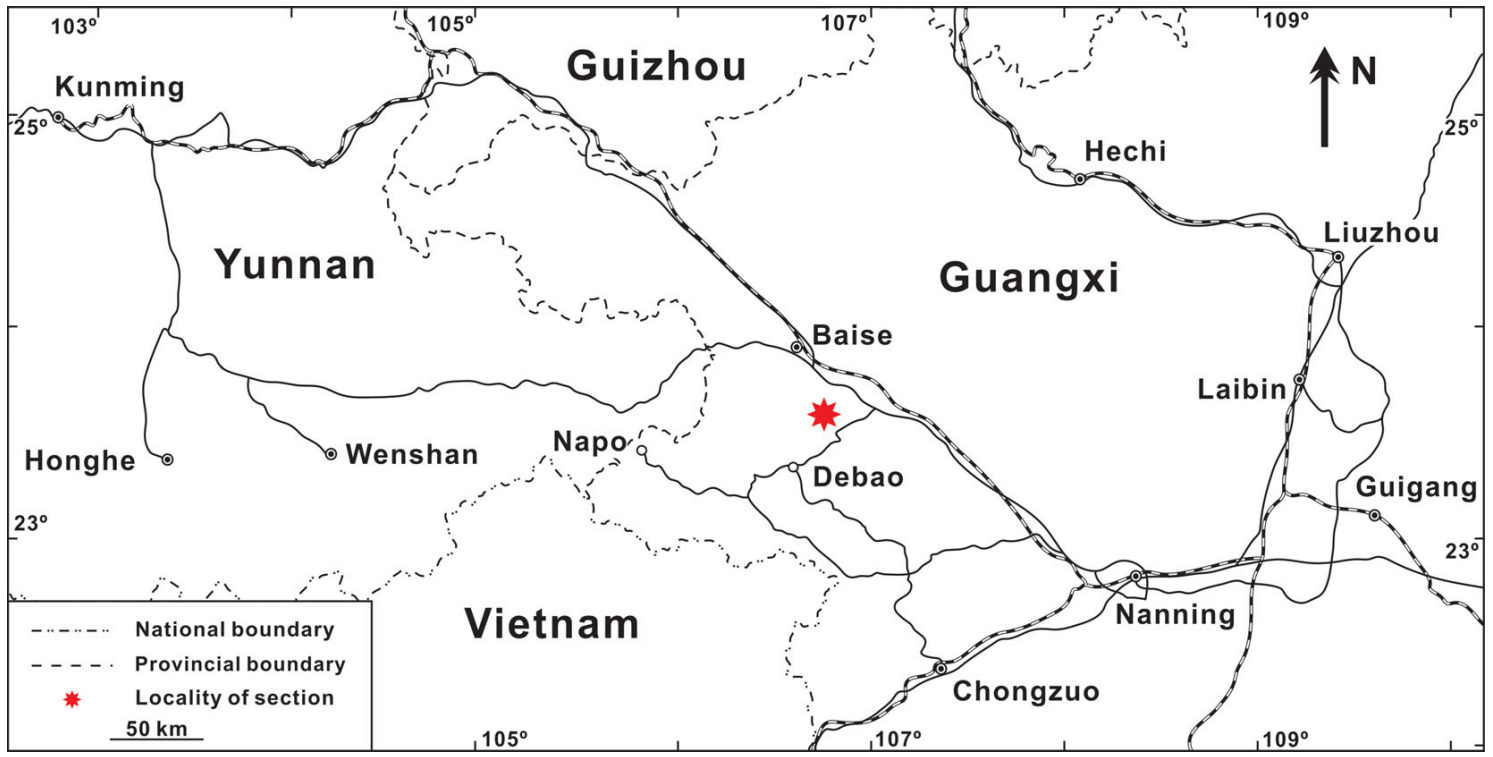

Figure 3. Locality of the Nalai section (red star mark) in Guangxi, South China.

\section{Results}

Polygnathus serotinus has its lowest occurrence in sample NL-10-5 in the middle part of Bed 10 (Figs 4, 8M, N) and ranges up to sample NL-13-3 in the middle part of Bed 13 (Figs 4, 8O-R, 9A-R). Bipennatus cf. B. montensis (Fig. 7A-C), a morphologically unique specimen that closely resembles $B$. montensis generally recorded from the Eifelian costatus Zone (Narkiewicz \& Narkiewicz 2010; Narkiewicz 2013), is collected in sample NL-10-6 that belongs here to the Emsian serotinus Zone. However, $B$. cf. B. montensis differs slightly from the holotype of B. montensis (Weddige 1977, pl. 6, fig. 95) in the position of the basal cavity and the development of the characteris- tic sulcus on the narrow platform, thus, probably representing a phylogenetically early form of B. montensis. The upper half of Bed 10 also recorded the successively first entries of $P$. cooperi cooperi (Fig. 7D-K), P. linguiformis bultyncki (Fig. 8A-L) and P. cracens (Fig. 7L-Q); the former two taxa range higher into the upper part of Bed 12 and the lower part of Bed 13 respectively, whereas the latter one has its last appearance in sample NL-12-1 in the basal part of Bed 12. Polygnathus linguiformis bultyncki and $P$. cooperi cooperi are common taxa in the serotinus Zone, and both can reach into the costatus Zone together with P. serotinus. Polygnathus cracens has a worldwide distribution but is restricted to the serotinus Zone. In summary, the lower part of the Beiliu Formation at the Nalai section 
Table 1. Distribution of conodont species and richness at the Nalai section.

\begin{tabular}{|c|c|c|c|c|c|c|c|c|c|c|c|}
\hline Samples & NL-9-1 & NL-10-1 & NL-10-2 & NL-10-3 & NL-10-4 & NL-10-5 & NL-10-6 & NL-10-7 & NL-10-8 & NL-10-9 & NL-10-10 \\
\hline Sample weight $(\mathrm{kg})$ & 1,645 & 3,63 & 2,605 & 2,744 & 3,512 & 6,02 & 2,065 & 3,782 & 2,175 & 3,635 & 3,895 \\
\hline Polygnathus serotinus & & & & & & 1 & & 1 & 2 & 3 & 1 \\
\hline Bipennatus cf. B. montensis & & & & & & & 1 & & & & \\
\hline Polygnathus cooperi cooperi & & & & & & & & 1 & & 3 & \\
\hline Polygnathus linguiformis bultyncki & & & & & & & & & 3 & 8 & 2 \\
\hline Polygnathus cracens & & & & & & & & & & & 1 \\
\hline Number of elements & & & & & & 1 & 1 & 2 & 5 & 14 & 4 \\
\hline
\end{tabular}

\begin{tabular}{|c|c|c|c|c|c|c|c|c|c|c|}
\hline Samples & NL-11-1 & NL-12-1 & NL-12-2 & NL-12-3 & NL-12-4 & NL-12-5 & NL-13-1 & NL-13-2 & NL-13-3 & NL-13-4 \\
\hline Sample weight $(\mathrm{kg})$ & 3,365 & 4,158 & 3,645 & 3,115 & 2,93 & 3,51 & 1,735 & 3,9 & 3,445 & 3,651 \\
\hline Polygnathus serotinus & & & & & & & 5 & 2 & 3 & \\
\hline \multicolumn{11}{|l|}{ Bipennatus cf. B. montensis } \\
\hline Polygnathus cooperi cooperi & & & & & 1 & & & & & \\
\hline Polygnathus linguiformis bultyncki & & 3 & & 3 & & 4 & 1 & & 1 & \\
\hline Polygnathus cracens & & 2 & & & & & & & & \\
\hline Number of elements & & 5 & & 3 & 1 & 4 & 6 & 2 & 4 & \\
\hline
\end{tabular}

covering an interval from the middle part of Bed 10 to the lowermost part of Bed 12 is assigned to the serotinus Zone, whereas the precise zonal assignation of the interval ranging from samples NL-12-2 to NL-13-4 still needs a further study (Fig. 4).

One Zdimir bed was recognized from the upper part of Bed 10 in the lower part of the Beiliu Formation at the Nalai section (Figs 2B, 4). Additionally, few specimens of Zdimir were also collected at the base of Bed 13, just below sample NL-13-13. The study of the conodont biostratigraphy indicates that the Zdimir bed close to sample NL-10-10 belongs to the serotinus Zone.

\section{Conodont biostratigraphy of the Zdimir beds in South China}

Zdimir and Megastrophia are usually recorded together in South China and have important palaeoenvironmental and palaeoecological significances. Based on the lithology and faunal compositions, Wang et al. (1974) subdivided the marine Devonian strata in South China into the Xiangzhou facies and the Nandan facies. The former is mainly represented by bioclastic limestone, marlstone, and dolomite hosting rich benthic fossils, corresponds to an oxygen-rich and shallow sea environment, and could roughly be compared to the Rhenish facies in Europe; the latter mainly consists of black and dark grey mudstone and shale with abundant pelagic fossils, represents a deeper and quite sea environment, and can be compared to the Bohemian facies in Europe. Xian et al. (1980) subsequently broadened the concept of the Nandan facies by further classifying it into four lithofacies zones: the lithofacies zone of black mudstone, the lithofacies zone of limestone (intercalated with siliceous rocks), the lithofacies of siliceous rocks, and the lithofacies zone of limestone (with Zdimir) (Fig. 1). Characterized by yielding abundant specimens of Zdimir and Megastrophia, the lithofacies zone of limestone (with $Z d i$ mir), or the Zdimir lithofacies, is viewed as a transitional facies between the Xiangzhou facies and the Nandan facies and is suggested to represent a reef or reef mound environment (Xian et al. 1980, Bai \& Bai 1988, Bai et al. 1998). Later, Zhong et al. (1992) formally named this transitional lithofacies as the Beiliu facies. In the present paper, the Nandan facies is restricted to the other three lithofacies zones proposed by Xian et al. (1980) (Zdimir lithofacies is excluded). To study the stratigraphic distribution of Zdimir in South China, we have analyzed the conodont biostratigraphy of the Zdimir beds at six other sections that belong to the Beiliu facies or the Zdimir lithofacies (Fig. 5).

\section{Bahe section at Tiandeng}

Bai \& Bai (1988, fig. 2), Bai et al. (1994, fig. 10-5), and Bai et al. (1998) reported three Zdimir beds in the NajiaoZuozhou Formation at the Bahe section, Tiandeng (Fig. 1). The lowest Zdimir bed that contains the brachiopods Zdimir kueichouensis and Megastrophia sp. is located in the basal part of bed 1c; the second Zdimir bed with the same brachiopod taxa as the first one is situated in the lower part of bed 3; and the highest one hosting Z. kueichouensis, $Z$. contractus and Megastrophia sp. is close to the top of bed 11. Conodont succession of the Najiao-Zuozhou 
Formation suggests that the first and second Zdimir beds can be assigned to the serotinus Zone, whereas the third one belongs to the partitus Zone (Bai \& Bai 1988, Bai et al. 1994, 1998). However, when correlating the conodont biostratigraphy of the Zdimir beds at different sections in South China, Bai et al. (1998, tab. 1) correlated the second Zdimir bed at the Bahe section with the patulus Zone, an opinion that is inconsistent with the description in their paper (Bai et al. 1998, p. 374). Additionally, the joint occurrence of the rugose corals including Dohmophyllum beiluensis, Siphonophrentis cf. longiseptata and Tryplasma sp. with the brachiopods Z. kueichouensis and Megastrophia sp. in bed 3 indicates that this rugose coral fauna is assignable to the serotinus Zone.

\section{Dafengmen section at Beiliu}

Wang et al. (1965) first reported extraordinarily abundant specimens of the genus Zdimir (which was previously assigned to the genus Conchidiella) in the Guitang Formation (the previous Guitang Member of the Beiliu Formation) at the Dafengmen section (Fig. 1) and ascribed them to the Middle Devonian. Later, a comprehensive study on the brachiopods at this section was carried out by Wang \& Zhu (1979), who recognized three main Zdimir beds in the Guitang Formation (Fig. 6). The lowest Zdimir bed, located in bed BD634 in the lower half of the Guitang Formation, contains Zdimir gorezkii, Z. pseudobaschkiricus and Megastrophia uralensis; the second one is situated in the upper half of the Guitang Formation (bed BD643) and yields abundant specimens of Z. triangulicostatus, Z. gorezkii, Z. contractus, Z. baschkiricus, Z. pseudobaschkiricus, Z. strachovi, Z. beiliuensis, Z. quitangensis, M. uralensis and Carinatina arimaspa; the highest Zdimir bed is positioned in bed BD 646 close to the upper boundary of the Guitang Formation and hosts Z. triangulicostatus, Z. baschkiricus, Z. pseudobaschkiricus, Z. beiliuensis, M. uralensis and Eifelatrypa superplana. The strata at the Dafengmen section are characterized by containing abundant brachiopods and rugose corals, but no conodonts have ever been reported.

According to $\mathrm{Yu} \&$ Kuang (1982, pp. 44, 45), the rugose corals in the Guitang and the overlying Yarang formations at the Dafengmen section can be subdivided into three assemblages (Fig. 6. I-III). The first rugose coral assemblage (I) ranges from beds BD626 to 9-3 in the upper part of the lower half of the Guitang Formation and corresponds to the first Zdimir bed of Wang \& Zhu (1979). The second rugose coral assemblage (II) is situated in the upper part of the Guitang Formation; it ranges from beds BD643 to BD647 and includes the second and third Zdimir beds of Wang \& Zhu (1979). The third assemblage (III) includes rugose corals from beds BD652 to BD655 in the upper part of the Yarang Formation. Yu et al. (1979, pp. 98, 99), and

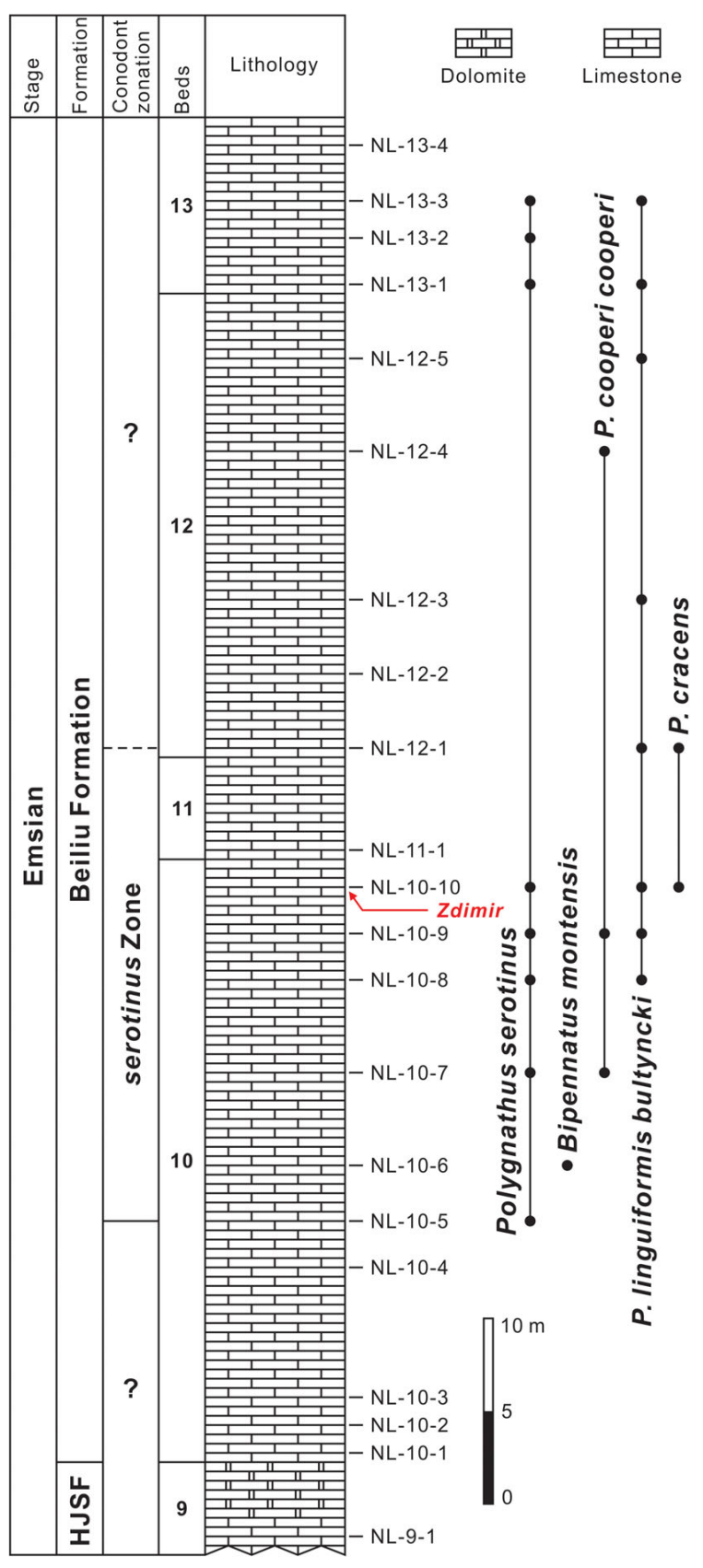

Figure 4. Stratigraphical column of the Emsian succession at the Nalai section with position of samples, conodont ranges and location of the Zdimir beds. HJSF, Huangjingshan Formation.

Yu \& Kuang (1982, p. 46) made a detailed comparison of the rugose coral faunas between the Dafengmen and Dale sections (Xiangzhou) and noted that the first rugose coral assemblage in the Guitang Formation at the Dafengmen section could be correlated with the $\mathrm{T}$ assemblage (or the Trapezophyllum cystosum assemblage) in the lower part of the Liuhui Member of the Sipai Formation at the Dale section in having Trapezophyllum cystosum, Thamnophyllum uniense, Tryplasma devoniana and 


\begin{tabular}{|c|c|c|c|c|c|c|c|c|}
\hline $\begin{array}{l}\mathscr{\Xi} \\
\stackrel{\Xi}{\infty}\end{array}$ & $\begin{array}{l}\text { Conodont } \\
\text { zonation } \\
\text { (Sandberg \& } \\
\text { Ziegler 1996) }\end{array}$ & $\begin{array}{c}\text { Nalai } \\
\text { (This paper) }\end{array}$ & $\begin{array}{c}\text { Bahe } \\
\text { (Bai \& Bai 1988, } \\
\text { Bai et al. 1998) }\end{array}$ & $\begin{array}{c}\text { Qinjia } \\
\text { (Wu \& Yan 1980) }\end{array}$ & $\begin{array}{c}\text { Dafengmen } \\
\text { (Wang \& Zhu } \\
\text { 1979) }\end{array}$ & $\begin{array}{c}\text { Guangziyao } \\
\text { (Wang \& Zhu } \\
1979)\end{array}$ & $\begin{array}{c}\text { Liujing } \\
\text { (Kuang et al. } \\
\text { 1989) }\end{array}$ & $\begin{array}{l}\text { Longmenshan } \\
\text { (Hou et al. 1988) }\end{array}$ \\
\hline 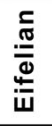 & partitus & & Zdimir & & & & & Zdimir \\
\hline \multirow{2}{*}{ 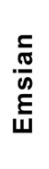 } & patulus & & & & & & & \\
\hline & serotinus & Zdimir & Zdimir & Zdimir & Zdimir & Zdimir & Zdimir & \\
\hline
\end{tabular}

Figure 5. Zonal correlation of the Zdimir beds in relevant sections of South China.

Embolophyllum. In addition to Dale section in the Xianzhou area, the $\mathrm{T}$ assemblage was only reported in the Luzhai and Wuxuan (Yu et al. 1979, p. 99; Yu \& Kuang 1982, p. 46), both of which are geographically close (approximately ninety kilometres, respectively) to the Dale section. According to Wang (1979), the conodont Polygnathus declinatus, a species initially thought to be transitional between $P$. inversus and $P$. serotinus by Wang (1979) but viewed as a junior synonym of $P$. serotinus by Klapper \& Vodrážková (2013) and present paper, was reported from the uppermost part of the Shipeng Member to the lowermost part of the Liuhui Member of the Sipai Formation. In addition, $P$. serotinus together with $P$. inversus and Nowakia holynensis was also obtained by Bai et al. (1982, p. 14) and Bai et al. (1994, p. 142) from the middle part of the Liuhui Member at the Dale section. The conodont evidences suggest that the lower and middle parts of the Liuhui Member of the Sipai Formation in the Xiangzhou area can be assigned to the serotinus Zone. Accordingly, the first rugose coral assemblage at the Dafengmen section, to which the first Zdimir bed of Wang \& Zhu (1979) corresponds, also belongs to the serotinus Zone (Fig. 5).

Yu \& Kuang (1982, p. 46) temporarily correlated the second rugose coral assemblage at the Dafengmen section with that from the Dingshanling Member of the Sipai Formation to the lower part of the overlying Yingtang Formation in the Xiangzhou area. However, rugose coral fauna reported by Bai et al. (1982, p. 14) and Bai et al. (1994, p. 141) in bed 36b of the Dingshangling Member at the Dale section is somewhat similar to the second rugose coral assemblage at the Dafengmen section in containing only Tryplasma guangxiensis, whereas fauna in the Yingtang Formation is completely not. According to Wang et al. (1979, p. 309) and Wang \& Ziegler (1983, p. 81), the Dingshanling Member of the Sipai Formation and the overlying lower part of the Yintang Formation are roughly assigned to the serotinus Zone and costatus Zone, respectively. However, due to the scarcity of conodonts from the upper part of the Dingshanling Member of the Sipai Formation, the precise levels of the patulus Zone and the partitus Zone at the Dale section remain unknown.

As aforementioned, the rugose corals including Dohmophyllum beiluensis, Siphonophrentis cf. longiseptata and Tryplasma sp. were only reported in the second Zdimir bed at the Bahe section (Bai \& Bai 1988; Bai et al. 1994, 1998). At the Dafengmen section, D. beiluensis was collected from bed BD646; S. longiseptata ranged from the middle to upper parts of the Guitang Formation; and the genus Tryplasma was common in the first and second rugose coral assemblages (Yu \& Kuang 1982; herein, Fig. 6). As a result, the second rugose coral assemblage at the Dafengmen section can be roughly correlated with the rugose coral fauna in bed 3 at the Bahe section and belongs to the serotinus Zone. Additionally, the correlation of the rugose coral taxa between the Dafengmen and Guanziyao sections (discussed further down in this paper) also strongly suggests the assignation of the second rugose coral assemblage in the Guitang Formation to the serotinus Zone. Accordingly, all three main Zdimir beds in the Guitang Formation at the Dafengmen section belong to the serotinus Zone (Fig. 5).

\section{Qinjia section at Debao}

Zdimir was recorded from beds 25 and 26 in the lower part of the Qunping Member of the Debao Formation at the Qinjia section (Fig. 1) (Wu \& Yan 1980, Xian et al. 1980). Wu \& Yan (1980, pp. 206, 207) compared the brachiopod and coral faunas between the Qinjia and Guixi-Shawozi sections, and suggested a rough correlation of the Qunping Member with the upper part of the Yangmaba Formation in the Longmenshan area that was assigned to the partitus Zone. They further stressed that the lower part of the Qunping Member was correlative with the Nowakia holynensis Zone, whereas the upper part was referred to the upper N. sulcata Zone. This opinion was later adopted by Bai 


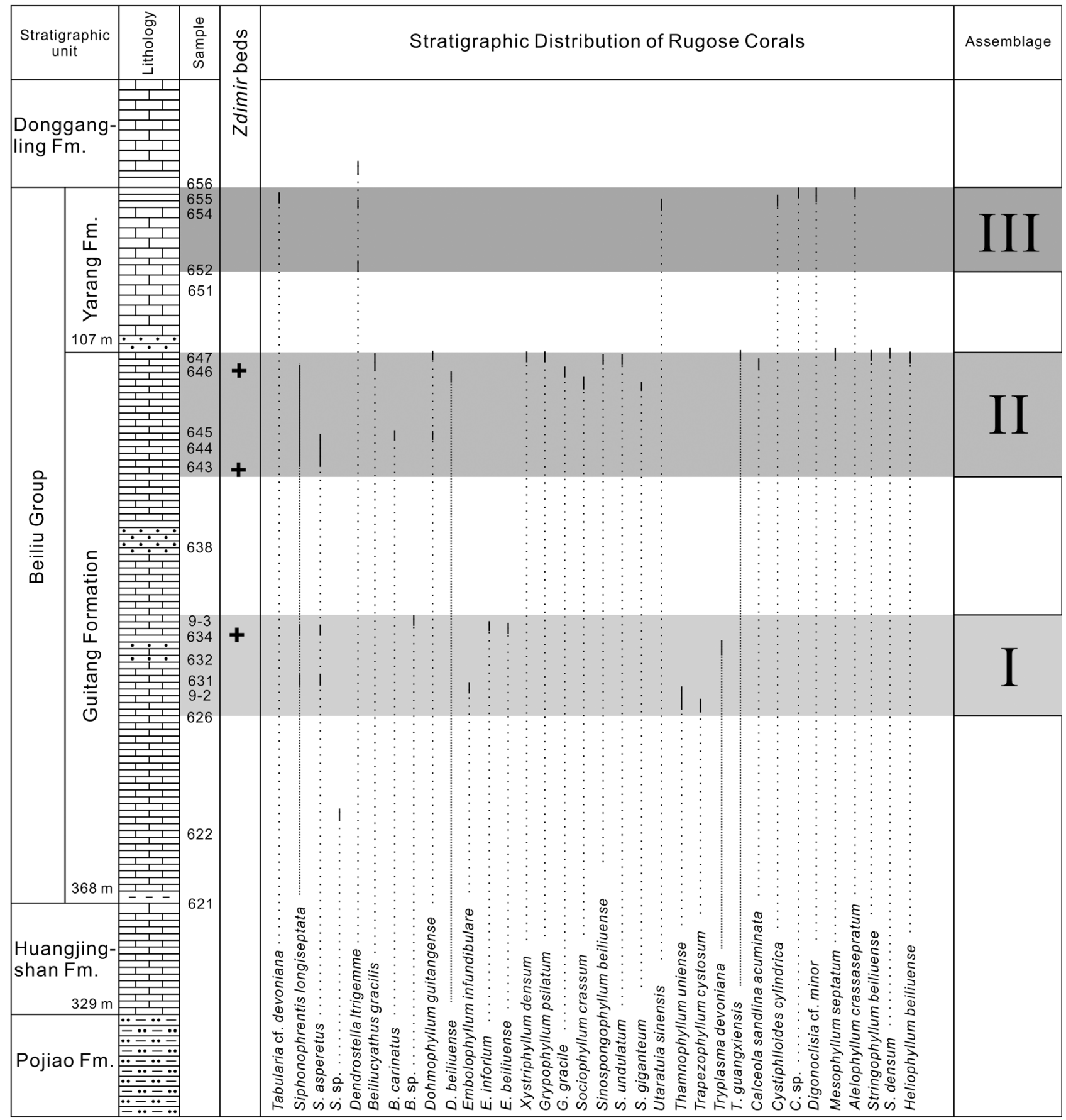

Figure 6. Stratigraphical distribution of rugose corals in the Beiliu Group at Dafengmen section, Guangxi (modified after Yu \& Kuang 1982). I-III represent the three rugose coral assemblages. The black crosses correspond to the three main Zdimir beds.

et al. (1998), who assigned the lower part of the Qunping Member to the patulus Zone. The interval containing only Megastrophia uralensis in the upper part of Qunping Member was viewed as the second Zdimir bed and they assigned it to the partitus Zone.

According to the conodont study conducted by Xiong (1981) at the Qinjia section, Polygnathus inversus, which commonly ranges from the inversus Zone to the serotinus Zone, was recorded in bed 25 in the basal part of the Qunping Member. Taking into consideration that Nowakia holynensis first appeared in the upper part of the underlying Duobang Member, the lower part of the Qunping Member should be assigned to the lower rather, than the upper, part of the $N$. holynensis Zone. Accordingly, as suggested by 
Xiong (1987, tab. 1), Zdimir in beds 25 and 26 in the lower part of the Qunping Member belongs to the serotinus Zone (Fig. 5). The second Zdimir bed proposed by Wu \& Yan (1980), and Bai et al. (1998) in the upper part of the Qunping Member should better be named the Megastrophia bed. However, its precise position regarding conodont biozones is unknown because of the absence of diagnostic taxa.

\section{Guanziyao section at Pu'an}

A preliminary study about the genus Zdimir (which was also previously assigned to the genus Conchidiella) in the Guanziyao Formation at the Guanziyao section (Fig. 1) was first conducted by Hou \& Xu (1964). They described three new species of this genus and correlated the Guanziyao Formation with the middle part of the Middle Devonian in the Urals and Kuznetsk Basin on the basis of the correlation of the brachiopod taxa. Later, when restudying the brachiopod fauna at the Guanziyao section, Wang \& Zhu (1979, p. 15) reported abundant specimens of Zdimir in the lower half of the Guanziyao Formation at the Guanziyao section. Subsequently, Yu \& Kuang (1982, p. 48) made a detailed study of the rugose corals co-occurring with Zdimir in the Guanziyao Formation. They corroborated that many species or genera of rugose corals at the Guanziyao section such as Beiliucyathus gracilis, Dohmophyllum guitangense, Tryplasma guangxiense, Siphonophrentis, Stringophyllum and Sociophyllum can also be (or only be) observed in the second rugose coral assemblage at the Dafengmen section. As a result, the Zdimir bed in the Guanziyao Formation at the Guanziyao section can be directly correlated with the Zdimir beds in the upper part of the Guitang Formation at the Dafengmen section, which suggests that the stratigraphic level of the former cannot be lower than the serotinus Zone. Moreover, conodonts including Polygnathus cooperi secus, P. linguiformis alpha morphotype (= P. linguiformis bultyncki), $P$. foliformis (= P. serotinus) and Caudicriodus culicellus were obtained in the uppermost part of the Guanziyao Formation by Xiong (1987), indicating that the uppermost part of the Guanziyao Formation belongs to the serotinus Zone. Thus, the Zdimir bed at the Guanziyao section is assigned to the serotinus Zone (Fig. 5).

It is worthy to note that Bai et al. (1998) also agreed with the correlation of the rugose coral biostratigraphy between the Guanziyao and Dafengmen sections made by $\mathrm{Yu}$ \& Kuang (1982). Although the Zdimir bed at the Guanziyao section was correlated with the serotinus Zone by Bai et al. (1998), these Zdimir beds in the upper part of the Guitang Formation at the Dafengmen section were assigned to the patulus Zone.

\section{Other sections in South China}

Kuang et al. (1989, pp. 8, 71, fig. 13) reported the first appearance of Zdimir sp. together with Atrypa sp. and Megastrophia sp. in the upper part of bed 43 of the Najiao Formation at the Liujing section (Fig. 1). Polygnathus serotinus first appears in the lower part of bed 43, whereas $P$. costatus patulus has its first appearance in sample $\mathrm{Nj} 17$ in the middle or upper part of bed 44. As a result, the Zdimir bed that was initially assigned to the patulus Zone by Kuang et al. (1989, p. 57) is correlated with the serotinus Zone in the present paper (Fig. 5).

Abundant specimens of Zdimir were also collected by Hou et al. (1988) from bed B93 in the Shiliangzi Member of the Yangmaba Formation at the Guixi-Shawozi section, Longmenshan (in the northwest part of the South China Block). The joint occurrence of Polygnathus costatus partitus, Bipennatus bipennatus and B. montensis with Zdimir permits the assignation of beds B93-B94 of the Shiliangzi Member to the partitus Zone (Hou et al. 1988; herein, Fig. 5).

\section{Summary}

On the basis of the conodont succession at the Nalai section, one Zdimir bed in the lower part of the Beiliu Formation is assigned to the serotinus Zone. Taking into account the rugose coral biostratigraphy associated to Zdimir, the conodont biostratigraphy of the Zdimir beds at the Dafengmen, Liujing, Qinjia, Bahe, Guangziyao and Guixi-Shawozi sections in South China are also reviewed. Several Zdimir beds which were previously correlated with the patulus Zone at the Dafengmen, Bahe and Qinjia sections by Bai et al. (1998) in fact belong to the serotinus Zone. Accordingly, the Zdimir beds in South China can only be assigned to the upper Emsian serotinus Zone and to the lower Eifelian partitus Zone.

\section{Systematic Palaeontology}

All specimens described and illustrated herein are deposited in the collections of the Nanjing Institute of Geology and Palaeontology (NIGP). Only Pa elements are described. Nomenclature of the Pa elements proposed by Murphy \& Valenzuela-Ríos (1999) is followed.

Class Conodonta Pander, 1856

Order Ozarkodinida Dzik, 1976

Family Polygnathidae Bassler, 1925

\section{Genus Bipennatus Mawson, 1993}

Type species. - Spathognathodus bipennatus Bischoff \& Ziegler, 1957. 
Bipennatus cf. B. montensis (Weddige, 1977) Figures $7 \mathrm{~A}-\mathrm{C}$

cf. 1966 Spathognathodus cf. bipennatus Bischoff \& Ziegler. - Bultynck, pp. 202-203, pl. 2, figs 6-7 (only).

cf. 1970 Spathognathodus cf. bipennatus Bischoff \& Ziegler. - Bultynck, p. 134, pl. 19, figs 2, 4 (only).

cf. 1974 Eognathodus bipennatus (Bischoff \& Ziegler). Perry et al., pp. 1084, 1086, pl. 6, figs 14-15.

cf. 1977 Eognathodus bipennatus montensis n. ssp.; Weddige, p. 324, pl. 6, figs 95-96.

cf. 1983 Eognathodus bipennatus montensis Weddige. Wang \& Ziegler, pp. 92, 93, pl. 1, figs 15-16.

cf. 1988 Eognathodus bipennatus montensis Weddige. Xiong in Hou et al., p. 314, pl. 123, fig. 3.

cf. 1989 Eognathodus bipennatus montensis Weddige. Wang, p. 41, pl. 6, figs 4-7.

cf. 2010 Bipennatus bipennatus montensis (Weddige). - Narkiewicz \& Narkiewicz, p. 292, figs 5a-h.

cf. 2013 Bipennatus montensis (Weddige). - Narkiewicz, pp. 3, 5-6, figs 3a-v.

Material. - One Pa element from sample NL-10-6 (1).

Description. - The anterior fourth of the blade is composed of four almost equal, tip-free and very low denticles, slightly higher than the flat and smoothly descending middle blade. The anterior end is slightly bent. Posterior blade tapers posteriorly, gently bowed downwards and markedly descending with six broad, transversely elongated and very low denticles with the posterior one being the lowest. The lower margin is weakly concave with both anterior and posterior margins rising slowly from the end to the middle point of the blade. The blade is longitudinally straight. A flat, smooth and narrow upper platform is developed in the middle third of the blade above the basal cavity, tapers anteriorly and remains broad posteriorly; margins of this narrow platform are distinctly smooth and join together with the last denticle of the anterior blade at the anterior end of the platform. Basal lobes are slightly anterior of mid blade, rounded and asymmetrical with the outer one being larger. A small terrace area with brim is developed on both lobes. Basal cavity is completely open and extends anteriorly and posteriorly as a narrow groove.

Discussion. - Bipennatus montensis was first named and described as Eognathodus bipennatus montensis by Weddige (1977) in the Bergisches Land and Eifel Mountains, Germany. Later, when investigating the morphological variability and phylogenetic affinity of this taxon, Narkiewicz (2013) ascribed it to the genus Bipennatus and raised it to species level. The taxonomic treatment of Narkiewicz (2013) is followed in the present paper.

Bipennatus montensis closely resembles B. pennatus in the blade outline, but differs in having a shallow trough restricted to the middle part of the blade and flanked by two smooth marginal ridges, a more centrally located basal cavity, a relatively lower anterior blade, and a longitudinally straight blade. In contrast, B. pennatus has a clear trough or sulcus on the upper surface that nearly extends to the posterior termination and is bordered by two nodose marginal ridges; the basal cavity is somewhat more anteriorly located; the denticles in the anterior part of the blade are remarkably higher than the upper margin of the posterior part; and the posterior blade is clearly deflected inward.

The holotype of Bipennatus montensis (Weddige 1977, pl. 6, fig. 95) is characterized by a shallow sulcus on the narrow platform in the middle third of the blade, a basal cavity situated slightly posterior to the mid-length, and two lateral, semi-circular lobes without terrace on the upper surface. However, the Nalai specimen slightly differs from the holotype of B. montensis in having a flat, smooth and narrow upper platform surface in the absence of the characteristic shallow sulcus, a slightly anteriorly located basal cavity, and two terraced lobes. As a result, the Nalai specimen, provisionally identified as B. cf. B. montensis herein, probably represents a phylogenetically early form of this species.

Narkiewicz \& Narkiewicz (2010), and Narkiewicz (2013) pointed out that Bipennatus montensis was generally reported from the Eifelian costatus Zone in Germany, Poland and Russia. However, B. cf. B. montensis is described in the upper Emsian serotinus Zone at the Nalai section, a level which is much lower than the previously recorded. As a result, the Nalai's record challenges Narkiewicz's (2013) opinion about the phylogenetic position of $B$. montensis being derived from the ozarkodinids near the Emsian-Eifelian boundary. Compared with the Eifelian B. aff. B. montensis and Ozarkodina sp. A described by Narkiewicz (2013) from the Holy Cross Mountains, the Nalai material resembles more closely the holotype or the representative specimens of B. montensis, suggesting that $B$. montensis do not evolve from Ozarkodina sp. A via B. aff. B. montensis near the Emsian-Eifelian boundary.

Occurrence. - Bipennatus montensis has been widely recorded in the costatus Zone, but B. cf. B. montensis in the present study is reported from the serotinus Zone.

\section{Genus Polygnathus Hinde, 1879}

Type species. - Polygnathus dubius Hinde, 1879.

Polygnathus cooperi cooperi Klapper, 1971 Figures 7D-K

1968 Polygnathus webbi Stauffer. - Đurđanović, pp. 100-101, pl. 1, fig. 10 (only). 
1970 Polygnathus linguiformis linguiformis Hinde. - Bultynck, pp. 125-127, pl. 9, figs 8-11.

1971 Polygnathus linguiformis cooperi n. ssp.; Klapper, p. 64, pl. 1, figs 12-22; pl. 2, fig. 21.

non 1975 Polygnathus linguiformis cooperi Klapper. - Telford, pp. 44-48, pl. 8, figs 6-15.

1977 Polygnathus linguiformis cooperi Klapper. - Klapper in Ziegler, pp. 471-472, Polygnathus-pl. 9, figs 2-3.

1977 Polygnathus linguiformis cooperi Klapper. - Weddige, pp. 314-315, pl. 5, figs 93-94.

non 1978 Polygnathus linguiformis cooperi Klapper. - Apekina \& Mashkova in Kim et al., p. 47, pl. 77, figs 3, 9.

1978 Polygnathus cooperi cooperi Klapper. - Klapper et al., p. 108, pl. 2, figs 21-22, 29-30.

1979 Polygnathus cooperi Klapper. - Lane \& Ormiston, pp. 76, 77, pl. 3, fig. 27.

1980 Polygnathus cooperi cooperi Klapper. - Klapper \& Johnson, p. 452.

1980 Polygnathus linguiformis cooperi Klapper. - Bultynck \& Hollard, p. 43, pl. 2, figs 17, 19; pl. 3, figs 14-15 (only).

1985 Polygnathus cooperi cooperi Klapper. - Bultynck, pp. 282, 283, pl. 7, figs 5-6, 14 ?

1987b Polygnathus cooperi cooperi Klapper. - Mawson, pp. 264, 265, pl. 1, fig. 6 (only).

non 1989 Polygnathus cooperi cooperi Klapper. - Mawson \& Talent, pp. 248, 249, pl. 3, fig. 8.

1992 Polygnathus cooperi cooperi Klapper. - Bardashev, pp. 62, 63, , pl. 1, fig. 2 (only).

non 1992 Polygnathus cooperi cooperi Klapper. - Bardashev \& Ziegler, pp. 28, 29, pl. 6, figs 26, 29.

? 1994 Polygnathus cooperi cooperi Klapper. - Mawson \& Talent, pp. 54, 55, pl. 2, fig. 4.

non 1994 Polygnathus cooperi cooperi Klapper. - Talent \& Mawson, pp. 78, 79, pl. 2, fig. 18.

2002 Linguipolygnathus cooperi cooperi (Klapper). Bardashev et al., p. 421, text-figs 10, 15.42.

2009 Polygnathus cooperi cooperi Klapper. - Berkyová, p. 680 , figs $7 \mathrm{a}-\mathrm{d}$.

2012 Polygnathus cooperi cooperi Klapper. Saydam-Demiray \& Çapkinoğlu, p. 15, pl. 2, figs 17, 22 (only).

Material. - Five Pa elements from samples NL-10-7 (1), NL-10-9 (3) and NL-12-4 (1).
Description. - Free blade about $1 / 4$ to $1 / 3$ of the total length with 7-9 close, palisade denticles (Fig. 7D, E), decreasing gradually in height posteriorly. Carina, flanked by narrow and somewhat shallow adcarinal grooves in the anterior part of the platform, varies from stout fused denticles in the anterior half of the platform to a row of discrete denticles in the middle part; it does not reach the posterior tip and isolated denticles fuse with tongue transverse ridges. Platform is symmetrical or slightly asymmetrical with the carina being centrally positioned (Fig. 7E, F, H) or near the inner side (Fig. 7J). Anterior platform margins meet the blade at straight or acute angles; in most specimens the inner one meets the blade at a more anterior position. Platform margins in the anterior part are at same height and ornamented by short transverse ridges that grow longer posteriorly, mainly in the outer flank. In some specimens (Fig. 7F-K) the anterior part of the platform is marked by a clear constriction, forming a concave outer margin anteriorly; these specimens show an almost straight inner margin, and the carina reflects this shape by a clear inner deflection in the posterior half. Other specimens (Fig. 7D, E) develop subparallel margins, and the carina gently curves inward. The posterior part of the platform has a short and triangular tongue covered by 4-5 semi-crossed transverse ridges. On the lower side a large or medium-sized, symmetrical basal pit is situated in the anterior half. It continues anteriorly in an open anterior through that tapers distally. Narrow posterior through is with appressed flanks. Platform bows with posterior third clearly bent downwards.

Discussion. - In the type specimens of Polygnathus cooperi cooperi (Klapper 1971 pl. 1, figs 12-22; pl. 2, fig. 21), the apparently or weakly constricted anterior platform is relatively flat and ornamented by short transverse ridges which are separated from the carina by shallow adcarinal grooves; the inner margin is at same height with the rounded and smooth outer one; the small tongue is ornamented by one to three crossed or semi-crossed transverse ridges; and the basal pit is located in the anterior part of the platform. One specimen illustrated here (Fig. 7F) has a small tongue whose transverse ridges on the outer side are interrupted except for the last and continuous one. A similar development of the transverse ridges on the tongue is also observed in two specimens of $P$. cooperi cooperi (Klapper 1971, pl. 1, figs 18, 19). The specimens figured by Berkyová (2009, figs 7a, c, d) also possess one continuous or

Figure 7. A-C - Bipennatus cf. B. montensis (Weddige 1977), Pa element: lateral, upper and enlarged views of NIGP 164918, sample NL-10-6. - D-K - Polygnathus cooperi cooperi Klapper, 1971, Pa elements; D, E - lower and upper views of NIGP 164919, sample NL-10-7; F, G - upper and lower views of NIGP 164920, sample NL-10-9; H, I - upper and lower views of NIGP 164921, sample NL-10-9; J, K - upper and lower views of NIGP 164922, sample NL-12-4. • L-Q - Polygnathus cracens Klapper, Ziegler \& Mashkova, 1978, Pa elements; L, M - upper and lower views of NIGP 164923, sample NL-10-10; N, O - upper and lower views of NIGP 164924, sample NL-12-1; P, Q - lower and upper views of NIGP 164925, sample NL-12-1. Scale bars $=100 \mu \mathrm{m}$. All the specimens are deposited at the NIGP. 

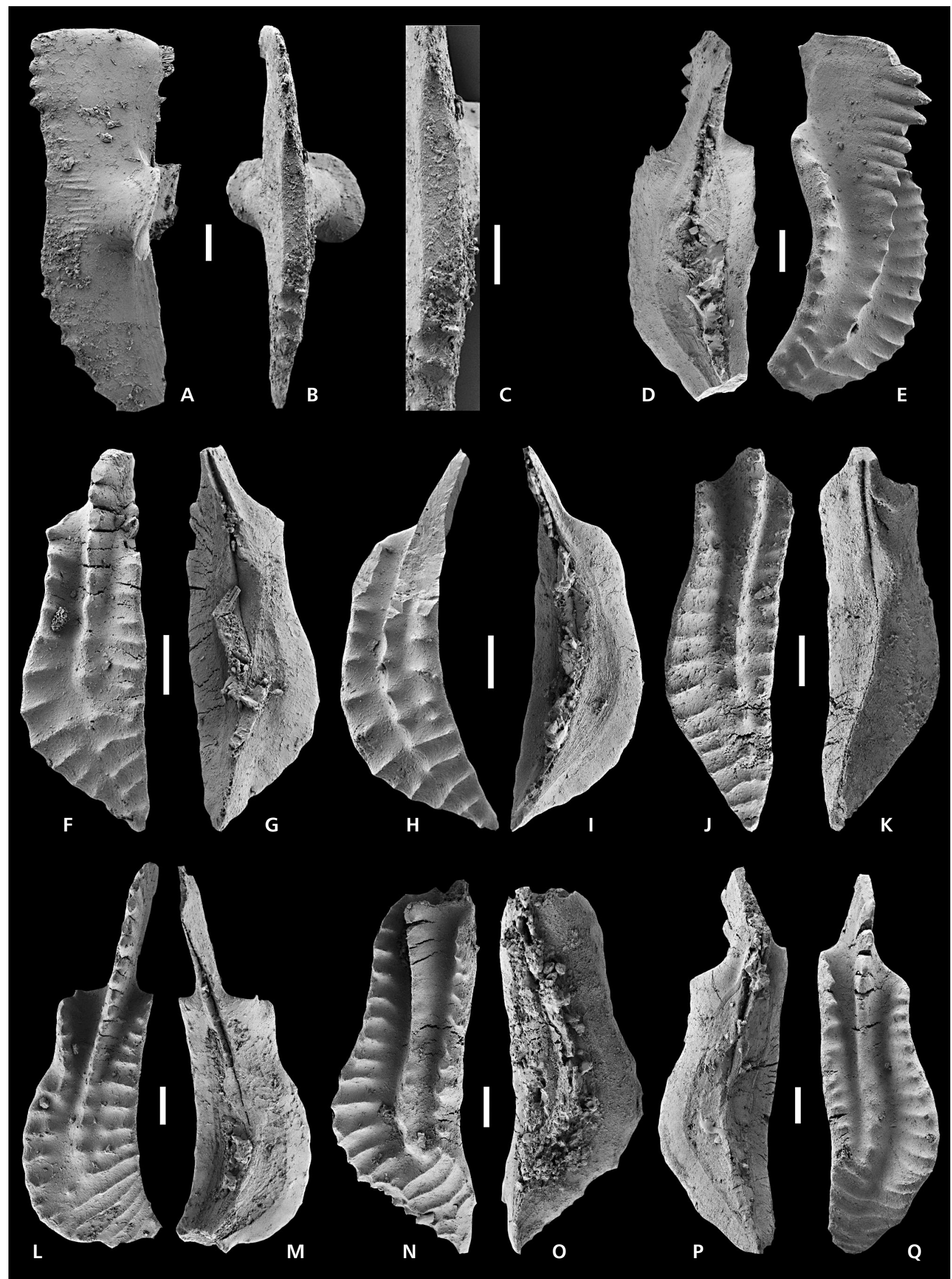
semi-crossed transverse ridge at the posterior end of the platform. Another specimen from the Nalai section (Fig. 7D, E) is similar to one of the original specimens (Klapper 1971, pl. 1, figs 20, 21) in having parallel inner and outer margins in the anterior part of the platform. The specimens reported as $P$. cooperi cooperi from Australia by Mawson \& Talent (1989, pl. 3, fig. 8; 1994, pl. 3, fig. 6), and Talent \& Mawson (1994, pl. 2, fig. 18) are characterized by interrupted transverse ridges at the posterior-end of the platform and a carina running to the posterior end.

Polygnathus cooperi cooperi differs from P. linguiformis butyncki by its weakly developed transverse ridges of which few completely cross the tongue, and the shallow adcarinal grooves only restricted to the anterior part. Polygnathus cooperi cooperi is highly differentiable by its distinctly straight, rather than serrate, anterior platform margin, whereas the anterior platform margin is strongly serrated in $P$. cooperi secus. Polygnathus costatus patulus has a carina extending to the posterior termination of the platform without the development of a tongue.

Occurrence. - This subspecies ranges from the serotinus Zone to the costatus Zone.

\section{Polygnathus cracens Klapper, Ziegler \& Mashkova, 1978}

Figures 7L-Q

1978 Polygnathus cracens n. sp.; Klapper, Ziegler \& Mashkova, p. 109, pl. 1, figs 17-20, 24-25.

1978 Polygnathus sp. H Klapper. - Apekina \& Mashkova in Kim et al., p. 46, pl. 76, figs 6-7.

1978 Polygnathus linguiformis Hinde alpha forma Bultynck. - Apekina \& Mashkova in Kim et al., p. 47, pl. 77, fig. 8 .

1978 Polygnathus linguiformis cooperi Klapper. - Apekina \& Mashkova in Kim et al., p. 47, pl. 77, figs 3, 9.

1980 Polygnathus cracens Klapper, Ziegler \& Mashkova. - Klapper \& Johnson, p. 452.

1985 Polygnathus cracens Klapper, Ziegler \& Mashkova. - Bultynck, pp. 282, 283, pl. 7, fig. 1.

1992 Polygnathus cracens Klapper, Ziegler \& Mashkova. - Bardashev \& Ziegler, pp. 28, 29, pl. 6, figs 5, $18 ?$
1992 Polygnathus cracens Klapper, Ziegler \& Mashkova. - Bonceva, p. 37, pl. 1, figs 5-6.

2002 Linguipolygnathus cracens (Klapper, Ziegler \& Mashkova). - Bardashev et al., p. 421, text-figs 10, 15.37 .

2009 Polygnathus linguiformis linguiformis Hinde. - Berkyová, pp. 682, 683, fig. 8i.

2012 Polygnathus cooperi cooperi Klapper. - SaydamDemiray \& Çapkinoğlu, p. 15, pl. 2, fig. 16.

Material. - Three Pa elements from samples NL-10-10 (1) and NL-12-1 (2).

Description. - High free blade is about $1 / 4$ of the total length and bears several laterally compressed denticles (Fig. 7L, M); its height gradually decreases posteriorly. Carina, located near the inner margin, varies from strongly fused denticles in the anterior part of the platform to a row of discrete denticles in the middle part. Platform is asymmetrically developed with a much wider and deeper outer adcarinal groove. Anterior platform margins commonly meet the blade at the same position with straight or acute angles (Fig. 7L-O). Anterior inner and outer platform margins are at same height and ornamented by short or slightly longer transverse ridges. Outer platform margin clearly constricted anteriorly. The posterior part of the platform is deflected inward and ornamented with numerous continuous transverse ridges; it represents about $1 / 3$ of the platform The outer margin at the conjunction of tongue and anterior platform is angular in most specimens, but in some specimens it continues in a rounded curve (Fig. 8C-H). On the lower side a small and symmetrical basal pit is situated anterior of the inward deflection of the posterior keel. It continues anteriorly in an open anterior through that tapers distally. Platform bows with posterior third clearly bent downwards.

Discussion. - Specimens from the Nalai section are characterized by an anteriorly constricted platform with the inner and outer margins having the same height, a welldeveloped tongue bearing numerous crossed transverse ridges, and a small, somewhat anteriorly situated basal pit. This combination of features is consistent with that shown in the representative specimens of Polygnathus cracens. However, the posterior part of the platform in the type specimens of $P$. cracens (Klapper et al. 1978, pl. 1, figs 17-20,

Figure 8. A-L-Polygnathus linguiformis bultyncki Weddige, 1977, Pa elements; A, B - upper and lower views of NIGP 164926, sample NL-10-8; C, D - upper and lower views of NIGP 164927, sample NL-10-9; E, F -lower and upper views of NIGP 164928, sample NL-10-9; G, H -lower and upper views of NIGP 164929, sample NL-10-9; I, J - lower and upper views of NIGP 164930, sample NL-10-10; K, L - lower and upper views of NIGP 164931, sample NL-13-1. M-R - Polygnathus serotinus Telford, 1975, Pa elements; M, N - upper and lower views of NIGP 164932, sample NL-10-5; O, P - lower and upper views of NIGP 164933, sample NL-10-8; Q, R - upper and lower views of NIGP 164934, juvenile specimen, sample NL-10-9. Scale bars $=100 \mu \mathrm{m}$. All the specimens are deposited at the NIGP. 

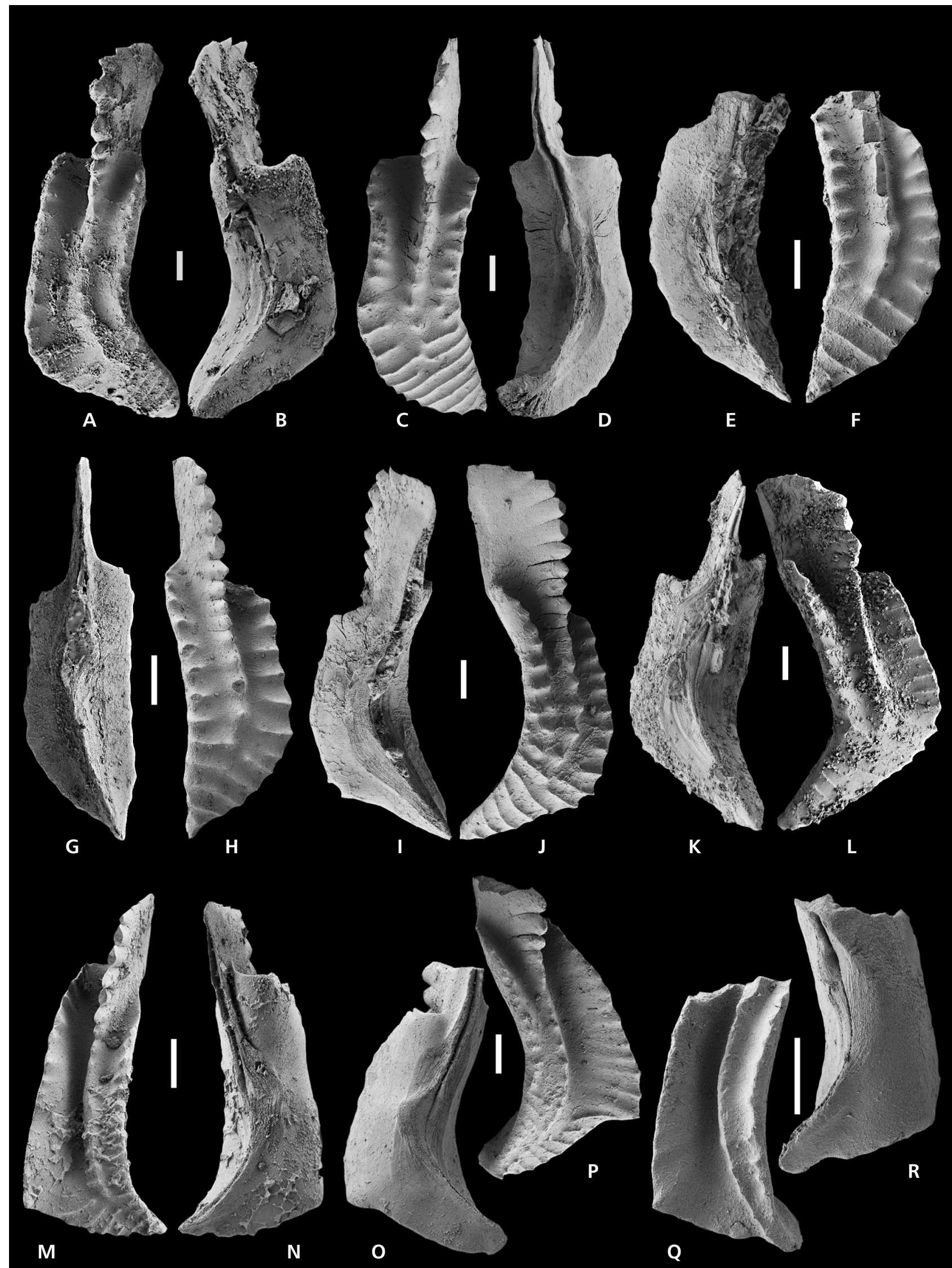
$24,25)$ is sharply deflected inward, whereas some of the Nalai specimens (Fig. 7N-Q) have a moderately deflected posterior part of the platform with an almost straight inner margin and a rounded outer one. Bultynck (1985, pl. 7, fig. 1) reported a similar specimen from Morocco.

Polygnathus inversus has a more or less parallel anterior inner and outer margins and a basal pit just anterior of the inward deflection of the keel; besides $P$. cracens has an anteriorly constricted platform and a more anteriorly situated basal pit. Polygnathus linguiformis bultyncki closely resembles $P$. cracens in the height of the anterior inner and outer margins and the position of the basal pit, but mainly the development of parallel anterior margins distinguishes $P$. linguiformis bultyncki from P. cracens.

Occurrence. - Polygnathus cracens is only recorded in the serotinus Zone.

\section{Polygnathus linguiformis bultyncki Weddige, 1977} Figures 8A-L

1975 Polygnathus linguiformis Hinde. - Snigireva, pp. 22, 23, pl. 4, fig. 5.

1977 Polygnathus linguiformis bultyncki n. ssp.; Weddige, pp. 313-314, pl. 5, figs 90-91; text-fig. 4.20 (only).

1982 Polygnathus linguiformis bultyncki Weddige. - Bai et al., p. 68, pl. 3, fig. 5; pl. 7, fig. 18.

1983 Polygnathus linguiformis bultyncki Weddige beta morphotype. - Wang \& Ziegler, p. 89, pl. 5, fig. 18.

1985 Polygnathus linguiformis linguiformis Hinde. - Ziegler \& Wang, pp. 30, 31, pl. 1, fig. 32.

1991 Polygnathus linguiformis bultyncki Weddige. Uyeno, pp. 156, 157, pl. 3, fig. 7.

1995 Polygnathus bultyncki Weddige. - Furey-Greig, pp. 230, 231, pl. 1, fig. 4.

1997 Polygnathus linguiformis cf. l. bultyncki Weddige. Savage \& Soja, p. 127, figs 3.3-3.5.

2003 Polygnathus linguiformis bultyncki Weddige. - Daniell, pp. 352, 353, pl. 4, figs 10-12.

2005 Polygnathus linguiformis bultyncki Weddige. - Jin et al., pp. 59-60, pl. 2, figs 3-4,13-14, 17-18.

2012 Polygnathus linguiformis bultyncki Weddige beta morphotype. - Saydam-Demiray \& Çapkinoğlu, p. 16, pl. 2, figs 9-10, 20 (only).
2013 Polygnathus bultyncki Weddige. - Klapper \& Vodrážková; pp. 164-167, text-figs 1a-f, 6a-f (further synonymy).

2013 Polygnathus linguiformis bultyncki Weddige. - Lu, pp. 316, 317, pl. 2, figs 2-3.

2015 Linguipolygnathus bultyncki (Weddige). - Aboussalam et al., pp. 946-949, figs 15v, 16a-b, h-j.

Material. - Twenty-five $\mathrm{Pa}$ elements from samples NL-10-8 (3), NL-10-9 (8), NL-10-10 (2), NL-12-1 (3), NL-12-3 (3), NL-12-5 (4), NL-13-1 (1) and NL-13-3 (1).

Description. - High free blade composed of 5-7 palisade denticles occupying about $1 / 5$ to $1 / 4$ of the total length (Fig. 8A-D, G-L); its height gradually decreases posteriorly. Carina, flanked by wide and deep adcarinal grooves, varies from strongly fused and stout denticles in the anterior half of the platform to a row of small discrete denticles in the middle part; carina ends at the beginning of the tongue. In most specimens, the anterior platform margins meet the blade at the same position with straight or acute angles. Platform is somewhat asymmetrical with a much deeper outer adcarinal groove. Anterior inner and outer platform margins have the same height and are ornamented by short transverse ridges. The posterior part of the platform is deflected inward and forms a well-developed triangular tongue that bears numerous continuous transverse ridges; it represents about $1 / 3$ of the platform. The outer margin at the conjunction of tongue and anterior platform is angular in most specimens, but in some specimens it continues in a rounded curve (Fig. 8C-H). On the lower side, a small to medium-sized and symmetrical basal pit is located anterior of the inward deflection of the keel. It continues anteriorly in an open anterior through that tapers distally. In slightly smaller specimen whose tongue is only ornamented by three or four continuous transverse ridges, the mediumsized basal pit is positioned more anteriorly between the mid-length and the anterior end of the platform (Fig. 8E-H). Platform bows with posterior third clearly bent downwards.

Discussion. - The Nalai specimens are similar to the type specimens of Polygnathus linguiformis bultyncki (Weddige 1977, pl. 5, figs 90-91) in the platform outline, tongue ornamentation, and position of the basal cavity. This taxon

Figure 9. A-R - Polygnathus serotinus Telford, 1975, Pa elements; A, B - upper and lower views of NIGP 164935, juvenile specimen, sample NL-10-9; C, D - lower and upper views of NIGP 164936, sample NL-10-10; E, F - lower and upper views of NIGP 164937, sample NL-13-1; G, H - lower and upper views of NIGP 164938, sample NL-13-1; I, J - lower and upper views of NIGP 164939, sample NL-13-1; K, L - lower and upper views of NIGP 164940, sample NL-13-1; M, N - lower and upper views of NIGP 164941, sample NL-13-2; O, P - lower and upper views of NIGP 164942, sample NL-13-3; Q, R - lower and upper views of NIGP 164943, sample NL-13-3. Scale bars $=100 \mu \mathrm{m}$. All the specimens are deposited at the NIGP. 


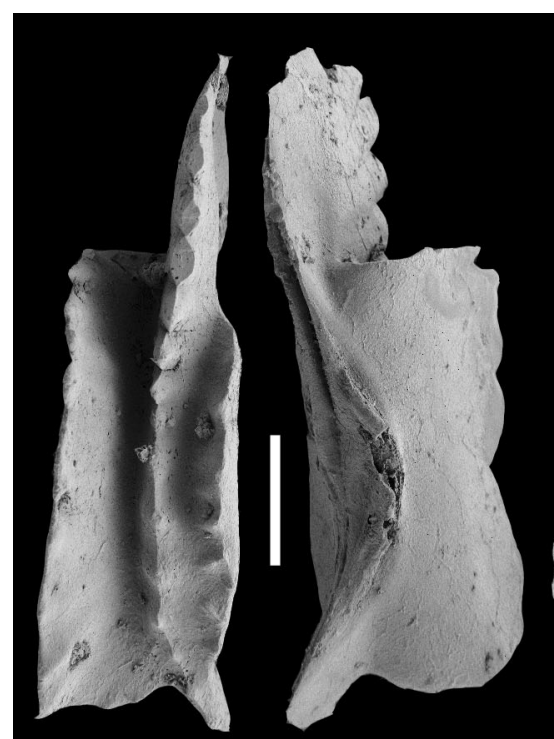

A

B
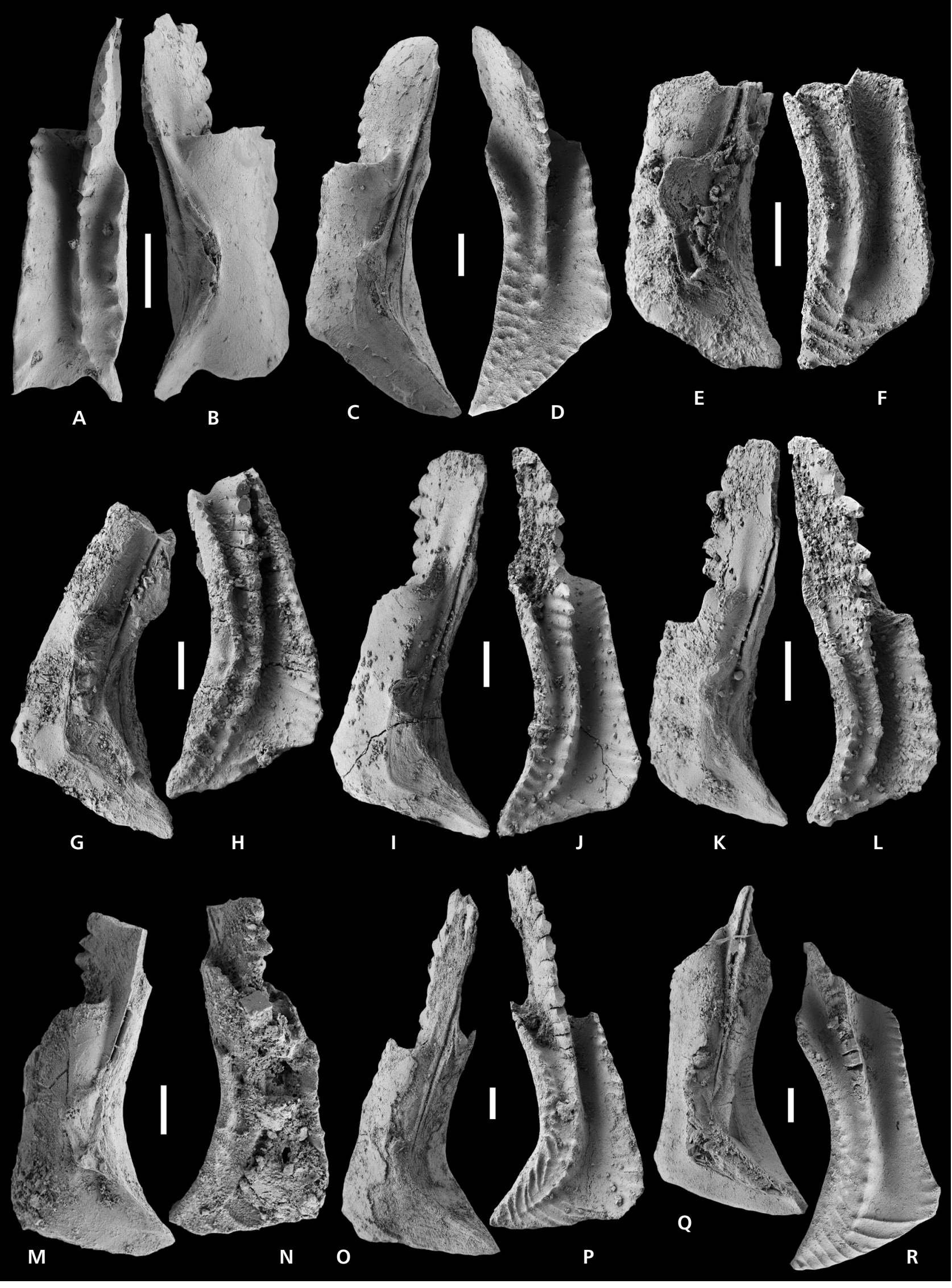
was initially depicted as the alpha morphotype of $P$. linguiformis linguiformis by Bultynck (1970). Differing from other six morphotypes (beta, gamma, delta, epsilon, zeta and eta) of $P$. linguiformis linguiformis which were summarized by Klapper in Ziegler (1977), P. linguiformis bultyncki is distinctly differentiable by the well-developed tongue that bears numerous continuous transverse ridges, the more or less parallel anterior inner and outer margins without the prominent flange-like development of the outer margin, and the deep adcarinal grooves (especially the outer one). Polygnathus linguiformis bultyncki shows a close similarity in the platform outline with $P$. inversus, from which it differs by the more anteriorly situated basal pit on the lower side.

Occurrence. -Polygnathus linguiformis bultyncki ranges from the serotinus Zone to costatus Zone (Klapper \& Vodrážková 2013).

\section{Polygnathus serotinus Telford, 1975}

Figures 8M-R, 9A-R

1975 Polygnathus foveolatus serotinus n. ssp.; Telford, pp. 43-44, pl. 7, figs 1-8.

1976 Polygnathus foveolatus n. ssp. Telford. - Fordham, pp. 80, 81, pl. 5, figs 5-8, 29, 30.

1978 Polygnathus linguiformis linguiformis Hinde. Wang \& Wang, p. 341, pl. 41, figs 15-17, 21-23.

1979 Polygnathus serotinus Telford. - Bai et al., p. 69, pl. 3, figs 7-10.

1979 Polygnathus serotinus Telford. - Lane \& Ormiston, p. 63 , pl. 7, figs 13,37 ; pl. 8, figs $2,6,8-10,10-13$, 19-22, 32-35.

1981 Polygnathus serotinus Telford. - Xiong, p. 194, pl. 1, figs 27-28.

1982 Polygnathus serotinus Telford. - Bai et al., p. 60, pl. 3, figs 7-10; pl. 8, figs 9-15.

1985 Polygnathus serotinus Telford. - Bultynck, pp. 278-281, pl. 5, figs 17-18; pl. 6, figs 3-4.

1987a Polygnathus serotinus Telford 'delta morphotype'. Mawson, pp. 278, 280, 282, pl. 33, figs 9-12; pl. 36, fig. 10.

1987a Polygnathus pseudoserotinus sp.; Mawson, pp. 277-278, pl. 35, figs 10-12; pl. 36, fig. 5 .

1988 Polygnathus serotinus Telford. - Bai \& Bai, pp. 532, 533, pl. 1, fig. 7.

1992 Polygnathus falcatus sp.; Bonceva, p. 42, pl. 5, figs $1-3$.

1992 Polygnathus pseudoserotinus Mawson. - Bonceva, pp. 40-41, pl. 6, figs 8-9.

1994 Polygnathus serotinus Telford. - Talent \& Mawson, pp. 78, 79, pl. 2, figs 15-17.

1997 Polygnathus serotinus Telford. - Savage \& Soja, p. 127, figs 3.11-3.22.
2005 Polygnathus pseudoserotinus Mawson. - Jin et al., pp. 63, 64, pl. 4, figs 12-17; pl. 13, figs 3-4, 11, 12.

2005 Polygnathus serotinus Telford gamma morphotype.Jin et al., p. 65, pl. 5, figs 7-14, 17; pl. 6, fig. 1.

2005 Polygnathus serotinus Telford delta morphotype. Jin et al., pp. 65-67, pl. 5, figs 15-16; pl. 6, figs 2-9; pl. 12, figs 15, 16; pl. 13, figs 13-16.

2012 Polygnathus serotinus Telford delta morphotype. Saydam-Demiray \& Çapkinoğlu, pp. 16, 17, pl. 2, figs $1-8$.

2013 Polygnathus serotinus Telford. - Klapper \& Vodrážková, pp. 158-159, 161, 164, text-figs 3a-g, 4a-h, 5a-f (further synonymy).

2013 Polygnathus serotinus Telford. - Lu, pp. 319, 320, pl. 4, figs 3-6.

2015 Linguipolygnathus serotinus (Telford). - Aboussalam et al., pp. 946, 947, figs $15 \mathrm{w}-\mathrm{x}$.

Material. - Eighteen Pa elements from samples NL-10-5 (1), NL-10-7 (1), NL-10-8 (2), NL-10-9 (3), NL-10-10 (1), NL-13-1 (5), NL-13-2 (2) and NL-13-3 (3).

Description. - High free blade composed of 6-7 palisade denticles decreasing gradually in height posteriorly and about $1 / 5$ to $1 / 4$ of the total length in adult specimens (Figs 8M, N, 9C, D, I, J, O, P), whereas it takes about $1 / 3$ in juvenile specimens (Fig. 9A, B, K, L). Asymmetrical platform with the carina near the inner margin. Carina varies from strongly fused denticles in the anterior part of the platform to a row of small discrete denticles in the posterior part, and may run to the posterior termination of the platform (Figs 8M, P, 9D, H, J, L) or just end before the tongue (Fig. 9F, P, R). Juvenile specimens may even have a carina extending one to two denticles posterior of the platform termination (Figs 8Q, R, 9A, B). Adcarinal grooves are asymmetrically developed, the outer one being much wider, deeper and extending far more posteriorly than the inner one. Platform margins in the anterior part are more or less parallel, and the outer margin is remarkably higher than the carina and inner margin due to its prominent flange-like development. Anterior platform margins meet the blade at straight or acute angles; in some specimens the inner one meets the blade at a slightly different position (Figs 8M, $\mathrm{N}, 9 \mathrm{~A}, \mathrm{~B}, \mathrm{M}-\mathrm{P})$. The outer platform is strongly deflected inward posteriorly, forming a rounded, quadrate or angular outline. On the lower side, a small basal pit is situated just anterior of the sharply inward deflection of the keel. A shelf-like protuberance or bulge with variable outlines is developed on the outer side of the pit, but it may be barren or weakly developed in some juvenile specimens (Figs 8Q, R, 9A, B).

Discussion. - Polygnathus serotinus easily differs from $P$. inversus, $P$. linguiformis bultyncki and $P$. quadratus in 
the presence of a shelf-like protuberance or bulge on the outer side of the pit. Polygnathus vigierei is distinctly differentiable by the clearly constricted anterior part of the platform and the randomly distributed nodes on the inner platform; $P$. apekinae lacks a shelf-like protuberance or bulge on the outer side of the pit.

Lane \& Ormiston (1979) recognized three morphotypes (alpha, beta, and gamma) of Polygnathus serotinus mainly on the basis of the different outlines of the tongue on the upper side and the constitutions of the protuberance on the lower side. Later, the alpha or early morphotype of Lane \& Ormiston (1979) was formally termed P. pseudoserotinus by Mawson (1987a), and $P$. serotinus was only restricted to the beta and gamma morphotypes of Lane \& Ormiston (1979). However, Klapper \& Vodrážková (2013) treated some supposedly transitional forms between $P$. inversus and $P$. serotinus (Klapper \& Johnson 1975, pl. 3, figs 19-22, 24-31; Uyeno \& Klapper 1980, pl. 8.1, figs 13-16) as the alpha morphotype of Lane \& Ormiston (1979) due to their close similarity on the lower side. As suggested by Uyeno \& Klapper (1980, p. 89), and Klapper \& Vodrážková (2013, p. 161), the anterior outer and inner margins have the same height in these intermediate forms; whereas Mawson (1987a, p. 277) maintained that the anterior outer margin is higher than the inner margin in $P$. pseudoserotinus. Accordingly, $P$. pseudoserotinus is accepted as a junior synonym of $P$. serotinus herein.

Klapper \& Vodrážková (2013) also made a detailed morphological analysis of Polygnathus serotinus and recognized three informal morphotypes of this species based on the outline of the shelf-like protuberance on the outer side of the pit. In the present paper, morphotype 1 (Figs 8N, 9E, K, M, O) and morphotype 2 (Figs 8O, 9C, G, I) of Klapper \& Vodrážková (2013) are both collected, whereas one juvenile specimen (Fig. 9B) with an incipient shelf-like bulge on the outer side of the pit extending farther to the posterior end corresponds to morphotype 3 of Klapper \& Vodrážková (2013).

Occurrence. - This taxon ranges from the serotinus Zone to the lower part of the costatus Zone (Klapper \& Vodrážková 2013).

\section{Acknowledgements}

We thank Sofie Gouwy and Stanislava Vodrážková for their important suggestions and comments, from which we have benefited greatly. The hospitality and care of Carlos Martínez-Pérez is also appreciated. National Natural Science Foundation of China $(41272009,41530103,41290260)$ funded this study. J.C. Liao is supported by the MINECO (Juan de la Cierva Postdoctoral Program, Ref. FJCI-2015-26813). This research is also a contribution to the $1^{\text {st }}$ IMERP XIV EJIP (2016, Alpuente, Spain).

\section{References}

Aboussalam, Z., Becker, R.T. \& Bultynck, P. 2015. Emsian (Lower Devonian) conodont stratigraphy and correlation of the Anti-Atlas (Southern Morocco). Bulletin of Geosciences 90, 893-890. DOI 10.3140/bull.geosci.1534

Andronov, S.M. 1961. Some representatives of the family Pentameridae from the Devonian deposits in the environs of the city Severouralsk. Trudy Geologischeskogo Instituta, Akademiya Nauk SSSR 55, 1-136. [in Russian]

BAI, S.L., BAI, Z.Q., MA, X.P., WANG, D.R. \& Sun, Y.L. 1994. Devonian Events and Biostratigraphy of South China. 303 pp. Peking University Press, Beijing.

BAI, S.L., JIN, S.Y. \& NING, Z.S. 1982. The Devonian biostratigraphy of Guangxi and adjacent area. 203 pp. Peking University Press, Beijing. [in Chinese]

BAI, S.L., Ning, Z.S., Jin, S.Y., Ho, J.H. \& HaN, Y.J. 1979. Devonian Platform Conodonts and Nowakiids of Kwangsi. Acta Scientiarum Naturalium Universitatis Pekinensis 4, 57-84. [in Chinese]

BAI, Z.Q. \& BAI, S.L. 1988. Conodont biostratigraphy of the Devonian Zdimir from Bahe, Guangxi, China, 529-534. In McMillan, N.J., Embry, A.F. \& Glass, D.J. (eds) Devonian of the World: Volume III. Canadian Society of Petroleum Geologists, Memoir 14.

BAI, Z.Q., BAI, S.L. \& WANG, P. 1998. Paleoenvironment and Correlation of Devonian Transitional Facies Beds (Zdimir Beds), South China, 373-378. In Department of Geology, Peking University (ed.) Collected Works of International Symposium on Geological Science Held at Peking University, Beijing, China. Peking University Press, Beijing. [in Chinese with English abstract]

Bardashev, I.A. 1992. Conodont Stratigraphy of Middle Asian Middle Devonian. Courier Forschungsinstitut Senckenberg 154, 31-83.

Bardashev, I.A., Weddige, K. \& Ziegler, W. 2002. The phylomorphogenesis of some Early Devonian platform conodonts. Senckenbergiana Lethaea 82, 375-451. DOI 10.1007/BF03042946

BARDASHEV, I.A. \& ZiEgLER, W. 1992. Conodont biostratigraphy of Lower Devonian deposits of the Shishkat section (southern Tien-Shan, Middle Asia). Courier Forschungsinstitut Senckenberg 154, 1-29.

BASSLER, R. 1925. Classification and stratigraphic use of the conodonts. Geological Society of America Bulletin 36, 218-220.

BerkyovÁ, S. 2009. Lower-Middle Devonian (upper EmsianEifelian, serotinus-kockelianus zones) conodont faunas from the Prague Basin, the Czech Republic. Bulletin of Geosciences 84, 667-686. DOI 10.3140/bull.geosci.1153

Bischoff, G. \& Ziegler, W. 1957. Die Conodontenchronologie des Mitteldevons und des tiefsten Oberdevons. Abhandlungen des Hessischen Landesamtes für Bodenforschung 22, 1-136.

BonCEVA, I. 1992. Emsian representatives of the conodont genus Polygnathus Hinde, 1879 from Southwest Bulgaria. Geologica Balcanica 22, 33-45. 
Boucot, A.J. \& SieHL, A. 1962. Zdimir Barrande (Brachiopoda) redefined. Notizblatt des Hessischen Landesamtes für Bodenforschung zu Wiesbaden 90, 117-131.

Bultynck, P. 1966. Répartition stratigraphique de quelques conodontes dans le Couvinien. Annales de la Société Géologique de Belgique 89, 189-206.

Bultynck, P. 1970. Révision stratigraphique et paléontologique (brachiopodes et conodontes) de la coupe type du Couvinien. Mémoires de l'Institut Géologique de l'Université de Louvain 26, 1-152.

Bultynck, P. 1985. Lower Devonian (Emsian)-Middle Devonian (Eifelian and lowermost Givetian) conodont successions from the Ma'der and the Tafilalt, southern Morocco. Courier Forschungsinstitut Senckenberg 75, 261-286.

Bultynck, P. \& Hollard, H. 1980. Distribution comparée de Conodontes et Goniatites dévoniens des plaines du Dra, du Ma'der et du Tafilalt (Maroc). Aardkundige Mededelingen 1, $7-75$.

Chen, X.Q. \& Liao, Z.T. 2006. Discovery of the Brachiopod Zdimir from the Devonian in the west of South Tianshan. Acta Palaeontologica Sinica 45, 351-358. [in Chinese with English abstract]

Chen, X.Q. \& Tazawa, J.I. 2003. Middle Devonian (Eifelian) brachiopods from the southern Kitakami Mountains, northeast Japan. Journal of Paleontology 77, 1040-1052. DOI 10.1666/0022-3360(2003)077<1040:MDEBFT>2.0.CO;2

DANIELL, J.J. 2003. Sedimentology, conodont biostratigraphy, and palaeogeography of a mid-Devonian carbonate/siliciclastic platform margin, Broken River region, north-eastern Australia. Courier Forschungsinstitut Senckenberg 245, 327-355.

ĐuRĐANOvić, Ž. 1968. Konodonte donjeg devona i donjeg karbona zapadno od Dvora na Uni (Hrvatska-Jugoslavija). Geološki Vjesnik 21, 93-105.

DZIK, J. 1976. Remarks on the evolution of Ordovician conodonts. Acta Palaeontologica Polonica 21, 395-455.

Fordham, B.G. 1976. Geology and Lower-Middle Devonian coral conodont biostratigraphy of the Nogoa Anticline, Springsure District, central Queensland. Proceedings of the Royal Society of Queensland 87, 63-76.

Furey-Greig, T. 1995. The "Nemingha" and "Loomberah" limestones (Early Devonian, Emsian) of the Nemingha-Nundle area, northern New South Wales: Conodont data and inferred environments. Courier Forschungsinstitut Senckenberg 182, 217-233.

HindE, G.J. 1879. On conodonts from the Chazy and Cincinnati Group of the Cambro-Silurian, and from the Hamilton and Genesee-Shale divisions of the Devonian, in Canada and the United States. Quarterly Journal of the Geological Society $35,351-369$. DOI 10.1144/GSL.JGS.1879.035.01-04.23

Hou, H.F., Wan, Z.Q., XIan, S.Y., Fan, Y.N., TANG, D.Z. \& WANG, S.T. 1988. Devonian stratigraphy, paleontology and sedimentary facies of Longmenshan, Sichuan. 487 pp. Geological Publishing House, Beijing. [in Chinese]

Hou, H.F \& Xian, S.Y. 1975. The Lower and Middle Devonian brachiopods from Kwangsi and Guizhou. Professional Papers of Stratigraphy and Palaeontology 1, 1-85. [in Chinese]

Hou, H.F. \& Xu, G.R. 1964. Discovery and its significance of Conchidiella from western Guizhou. Acta Palaeontologica Sinica 12, 572-592. [in Chinese with Russian summary]

IvANOvA, E.A. 1962. Ecology and development of the Silurian and Devonian Brachiopods of the Kuznetzk, Minussinsk, and Tuva basins. Akademiia Nauk SSSR, Paleontologičeskij Institut, Trudy 88, 3-152. [in Russian]

JiN, S.Y., SHEN, A.J., ChEN, Z.L., Lu, J.M., WeI, M., WANG, Y.Q. \& XIE, F. 2005. Mixed Biostratigraphy of Devonian in Wenshan, Yunnan. 195 pp. Petroleum Industry Press, Beijing. [in Chinese]

Kim, A.I., Yolkin, E.A., ERINA, M.V. \& GRATSIANOVA, R.T. 1978. Field Session of the International Subcommission on Devonian Stratigraphy, Samarkand, USSR, 1-55. In Sokolov, B.S. \& Garkovets, V.G. (eds.) Type sections of the Lower and Middle Devonian boundary beds in Middle Asia, A Guide to Field Excursions. Atlas of paleontological plates. Supplement to Guide of the Field Excursion.

KLAPPER, G. 1971. Sequence within the conodont genus Polygnathus in the New York lower Middle Devonian. Geologica et Palaeontologica 5, 59-79.

Klapper, G. \& Johnson, D.B. 1975. Sequence in conodont genus Polygnathus in lower Devonian at Lone Mountain, Nevada. Geologica et Palaeontologica 9, 65-83.

KLApper, G. \& Johnson, J.G. 1980. Endemism and dispersal of Devonian conodonts. Journal of Paleontology 54, 400-455.

KlapPER, G. \& VodRÁŽKOVÁ, S. 2013. Ontogenetic and intraspecific variation in the late Emsian-Eifelian (Devonian) conodonts Polygnathus serotinus and $P$. bultyncki in the Prague Basin (Czech Republic) and Nevada (western US). Acta Geologica Polonica 63, 153-174.

DOI 10.2478/agp-2013-0006

Klapper, G., Ziegler, W. \& Mashkova, T.V. 1978. Conodonts and correlation of Lower-Middle Devonian boundary beds in the Barrandian area of Czechoslovakia. Geologica et Palaeontologica 12, 103-116.

KRILOVA, A.K. 1962. Stratigraphy and brachiopods of the Devonian of the Siberian Platform. Trudy Vsesoyusnogo Neftyanogo Nauchno-Issledovatelskogo Geologorasvedochnogo Instituta 200, 1-108. [in Russian]

Kuang, G.D., Zhao, M.T. \& Tao, Y.B. 1989. Liujing Section of Guangxi-The Standard Devonian Section of China. 145 pp. China University of Geosciences Press, Wuhan. [in Chinese with English summary]

LANE, H.R. \& ORmiston, A.R. 1979. Siluro-Devonian biostratigraphy of the Salmontrout River area, East-central Alaska. Geologica et Palaeontologica 13, 39-96.

Lu, J.F. 2013. Late Emsian (Lower Devonian) conodonts from Bahe section, Tiandeng County, Guangxi. Acta Palaeontologica Sinica 52, 309-330. [in Chinese with English abstract]

MALYGINA, A.A. \& SAPELNIKov, V.P. 1973. Silurian, Early Devonian, and Eifelian Pentamerida of the southern Tien Shan. 
Akademia Nauk SSSR, Uralskii Nauchnyi Tsentr, Trudy Instituta Geologii i Geokhimii 104, 1-212. [in Russian]

Mawson, R. 1987a. Early Devonian conodont faunas from Buchan and Bindi, Victoria, Australia. Palaeontology 30, 251-297.

Mawson, R. 1987b. Documentation of Conodont Assemblages across the Early Devonian-Middle Devonian Boundary, Broken River Formation, North Queensland, Australia. Courier Forschungsinstitut Senckenberg 92, 251-273.

Mawson, R. 1993. Bipennatus, a new genus of mid-Devonian conodonts. Memoirs of the Association of the Australasian Palaeontologists 15, 137-140.

Mawson, R. \& TAlent, J.A. 1989. Late Emsian-Givetian Stratigraphy and Conodont Biofacies-Carbonate Slope and Offshore Shoal to Sheltered Lagoon and Nearshore Carbonate Ramp-Broken River, North Queensland, Australia. Courier Forschungsinstitut Senckenberg 117, 205-259.

Mawson, R. \& Talent, J.A. 1994. The Tamworth Group (Mid-Devonian) at Attunga, New South Wales; conodont data and inferred ages. Courier Forschungsinstitut Senckenberg $168,37-59$.

Murphy, M. \& VAlenzuela-Ríos, J.I. 1999. Lanea new genus, lineage of Early Devonian conodonts. Bollettino della Societa Paleontologica Italiana 37, 321-334.

NARkiewicz, K. 2013. Taxonomic revision and phylogenetic affinities of the conodont Bipennatus montensis (Weddige 1977) from the Eifelian (Middle Devonian) of Poland. Paläontologische Zeitschrift 87, 1-8.

NARkiewicz, K. \& NARkiewicz, M. 2010. Mid Devonian carbonate platform development in the Holy Cross Mts. area (central Poland): new constraints from the conodont Bipennatus fauna. Neues Jahrbuch für Geologie und Paläontologie, Abhandlungen 255, 287-300. DOI 10.1127/0077-7749/2009/0025

PANDER, C.H. 1856. Monographie der fossilen Fische des Silurischen Systems der Russisch Baltischen Gouvernements. 91 pp. Buchdrucherei der Kaiserlichen Akademie Wissenschaften, St. Petersburg.

Perry, D.G., Klapper, G. \& LenZ, A.C. 1974. Age of the Ogilvie Formation (Devonian), northern Yukon: based primarily on the occurrence of brachiopods and conodonts. Canadian Journal of Earth Sciences 11, 1055-1097. DOI 10.1139/e74-104

RzhonsnitskaiA, M.A. 1975. Biostratigrafiia Devona okrain Kuznetskogo Basseina, Tom 2, Opisanie brakhiopod, Chast' 1, Pentamerida i Atrypida. Trudy Vsesoiuznyi Ordena Lenina Nauchno-issledovatel'skii Geologicheskii Institut (new series) 244, 1-232. [in Russian]

Sandberg, C.A. \& Ziegler, W. 1996. Devonian conodont biochronology in geologic time calibration. Senckenbergiana Lethaea 76, 259-265. DOI 10.1007/BF03042852

SAvAGE, N.M. \& SojA, C.M. 1997. Lower to Middle Devonian (latest Emsian to earliest Eifelian) conodonts from the Alexander Terrane, southeastern Alaska. Alaska Division of Geological and Geophysical Surveys Professional Report 118, 125-129.

SAYdAM-DEMIRAY, D.G. \& ÇAPKINOĞLU, Ș. 2012. Conodont fauna and biostratýgraphy of the Early-Middle Devonian units in
Beykoz, Șile and Kurtdoğmuș Areas, İstanbul, Turkey. Bulletin of the Mineral Research and Exploration 145, 1-21.

SNIGIREVA, M.P. 1975. New Middle Devonian conodonts from the Northern Urals. Paleontological Journal 1975, 24-30.

SutTner, T.J. \& Chen, X.Q. 2009. Zdimir and related brachiopod faunas near the Emsian/Eifelian boundary in Austria and China. Berichte der Geologischen Bundesanstalt 79, 44-45.

Talent, J.A. \& Mawson, R. 1994. Conodonts in Relation to Age and Environmental Framework of the Burdekin Basin (Mid-Devonian), North-Eastern Australia. Courier Forschungsinstitut Senckenberg 168, 61-81.

TAZAWA, J.I. 1988. Zdimir (Devonian Brachiopoda) from the Kitakami Mountains, northeast Japan and its paleobiogeographical significance. Journal of the Geological Society of Japan 94, 1013-1016. [in Japanese]

DOI 10.5575/geosoc.94.1013

Telford, P.G. 1975. Lower and middle Devonian conodonts from the Broken River Embayment, North Queensland, Australia. Special papers in Palaeontology 15, 1-96.

Uyeno, T.T. 1991. Pre-Famennian Devonian conodont biostratigraphy of selected intervals in the eastern Canadian Cordillera. Geological Survey of Canada, Bulletin 417, 129-161. DOI 10.4095/132436

Uyeno, T.T. \& Klapper, G. 1980. Summary of conodont biostratigraphy of the Blue Fiord and Bird Fiord formations (Lower-Middle Devonian) at the type and adjacent areas, southwestern Ellesmere Island, Canadian Arctic Archipelago. Geological Survey of Canada, Paper 80-1C, 81-93.

WANG, C.Y. 1979. Some conodonts from the Sipai Formation in Xiangzhou of Guangxi. Acta Palaeontologica Sinica 18, 395-408. [in Chinese with English abstract]

WANG, C.Y. 1989. Devonian conodont of Guangxi. Memoris of Nanjing Institute of Geology and Palaeontology, Academia Sinica 25, 1-231. [in Chinese]

WANG, C.Y. \& WANG, Z.H. 1978. Early and Middle Devonian conodonts of Kwangsi and Yunnan province, 334-345. In Institute of Geology and Mineral Resources, Chinese Academy of Geological Sciences (ed.) Symposium on the Devonian System of South China. Geological Publishing House, Beijing. [in Chinese]

WANG, C.Y. \& Ziegler, W. 1983. Devonian conodont biostratigraphy of Guangxi, South China, and the correlation with Europe. Geologica et Palaeontologica 17, 75-107.

Wang, C.Y., Ruan, Y.P., Mu, D.C., Wang, Z.H., RonG, J.Y., YIN, B.A., KuANG, G.D. \& SU, Y.B 1979. Subdivision and correlation of the Lower and Middle Devonian series in different facies of Guangxi. Acta Stratigraphica Sinica 3, 305-311. [in Chinese]

Wang, Y., Yu, C.M., Fang, D.W., LiaO, W.H., Deng, Z.Q. \& ZHu, R.F. 1965. A new Middle Devonian stratigraphic unit in central and southern Guangxi-Beiliu Formation. Chinese Science Bulletin 12, 1116-1120. [in Chinese]

Wang, Y., Yu, C.M \& Wu, Q. 1974. Advances in the Devonian biostratigraphy of South China. Memoirs of Nanjing Institute of Geology and Palaeontology, Academia Sinica 6, 1-71. [in Chinese] 
WANG, Y. \& ZhU, R.F. 1979. Beiliu (Middle Middle Devonian) brachiopods from south Guizhou and central Guangxi. Palaeontologia Sinica, New Series B 15, 1-95. [in Chinese with English summary]

Weddige, K. 1977. Die Conodonten der Eifel-Stufe im Typusgebiet und in benachbarten Faziesgebieten. Senckenbergiana Lethaea 58, 271-419.

Wu, Y.\& YAN, C.X. 1980. Lower and Middle Devonian in Qinjia of Debao county, Guangxi. Acta Stratigraphica Sinica 4, 201-208. [in Chinese]

Xian, S.Y., Wang, S.D., Zhou, X.Y., Xiong, J.F. \& Zhou, T.R. 1980. Nandan typical stratigraphy and paleontology of Devonian in South China. 167 pp. Guizhou People's Press, Guiyang. [in Chinese]

XIONG, J.F. 1981. Preliminary investigation on Lower and Middle Devonian conodonts from the Qinjia County in Debao District of Guangxi and their significance in indicating facies. Experimental Petroleum Geology 8, 186-196.

XIONG, J.F. 1987. Preliminary investigation on Devonian conodont biostratigraphy and sedimentation facies in Guangziyao, Puan, Guizhou Province. Geology of Guizhou 10, $39-48$.

YoH, S.S. 1956. Subdivision, zonation and correlation of the
Devonian formations in Lungmenshan area, northwestern Szechuan. Acta Geologica Sinica 36, 443-476. [in Chinese with English summary]

Yolkin, E.A., Kim, A.I. \& Talent, J.A. 2008. Devonian sequences of the Kitab Reserve area: Field Excursion Guidebook. 97 pp. Publishing House of SB RAS, Novosibirsk.

YU, C.M. \& KUANG, G.D. 1982. Biostratigraphy, biogeography and paleoecology of Devonian rugose corals from the Beiliu Formation in Beiliu, Guangxi. Bulletin of Nanjing Institute of Geology and Paleontology, Academia Sinica 5, 41-82. [in Chinese with English abstract]

Yu, C.M., LiaO, W.H. \& Deng, Z.Q. 1979. The Sequence and Distribution of Devonian Coral Assemblages. Acta Stratigraphica Sinica 3, 96-102. [in Chinese]

Zhong, K., Wu, Y., Yin, B.A., Liang, Y.L., YaO, Z.G. \& Peng, J.L. 1992. Devonian of Guangxi. 384 pp. The Press of the China University of Geosciences, Wuhan.

ZIEGLer, W. 1977. Catalogue of conodonts, Volume III. 574 pp. E. Schweizerbart'sche Verlagsbuchhandlung, Stuttgart.

ZIEGLER, W. \& WANG, C.Y. 1985. Sihongshan section, a regional reference section for the Lower-Middle and Middle-Upper Devonian boundaries in East Asia. Courier Forschungsinstitut Senckenberg 75, 17-38. 